\title{
Macrobenthic community structure of the northeast Indian shelf, Bay of Bengal
}

\author{
T. Ganesh, A. V. Raman* \\ Marine Biological Laboratory, Department of Zoology, Andhra University, Waltair, Visakhapatnam 530003, India
}

\begin{abstract}
Knowledge of tropical benthic fauna is limited. Two cruises (January 1999 and July 2000) were made covering 24 stations along 5 transects between $16^{\circ}$ and $20^{\circ} \mathrm{N}$ in shelf waters (depth 30 to $200 \mathrm{~m}$ ) in the Bay of Bengal off northeast India. Altogether 62 infaunal samples (Smith-McIntyre grab $0.1 \mathrm{~m}^{2}$ ) and 32 epibenthos (through a naturalist dredge $40 \times 40 \mathrm{~cm}$ ) were collected that revealed 169 species representing 15 diverse groups. Gastropods, bivalves, polychaetes and decapods constituted the bulk of the population. Polychaetes were by far the most dominant group $(64.98 \%)$ among the infauna followed by amphipods $(25.23 \%)$, which were numerically more abundant (mean $1080 \pm 292$ ind. $\mathrm{m}^{-2}$ ) at 51 to $75 \mathrm{~m}$ than at greater depths $\left(345 \pm 185\right.$ ind. $\mathrm{m}^{-2}$ at $\left.>150 \mathrm{~m}\right)$. Biomass was higher (wet weight $6.94 \pm 4.8 \mathrm{~g} \mathrm{~m}^{-2}$ ) at 51 to $75 \mathrm{~m}$ than at 101 to $150 \mathrm{~m}\left(1.08 \pm 1.23 \mathrm{~g} \mathrm{~m}^{-2}\right)$. There was a preponderance of decapods (26\%), gastropods $(20.7 \%)$, bivalves $(8.3 \%)$ and several $(28.3 \%)$ largesized polychaetes (e.g. Diopatra neapolitana, Eunice indica, Pista sp.) in the dredge hauls (mean abundance $42 \pm 8$ ind. haul ${ }^{-1}$ ). Infaunal diversity (Shannon-Wiener $\left.H^{\prime}\right)$ was higher $\left(H^{\prime}: 2.455 \pm 0.18\right.$ ) at 51 to $75 \mathrm{~m}$ relative to the sites at $>150 \mathrm{~m}$ depth $\left(H^{\prime}: 0.981 \pm 0.17\right)$. Multivariate analyses were used to define assemblages named after the most important (determining) taxon. Three epifaunal associations could be recognised off the northeast Indian shelf, namely the Charybdis Assemblage (30 to $50 \mathrm{~m}$ ), the Liagore Assemblage (51 to $75 \mathrm{~m}$ ), and the Amygdalum watsoni-Tibia delicatula Assemblage (>100 m). Infaunal associations consisted of Ampelisca (30 to $75 \mathrm{~m}$ ), Nephtys (76 to $100 \mathrm{~m}$ ) and Cossura coasta (>100 m). Canonical correspondence analysis (CCA) showed that depth, sand, sediment organic matter and sediment mean size influenced epifauna distribution, whereas for infauna, salinity, temperature, mean particle diameter, sand and depth proved important.
\end{abstract}

KEY WORDS: Macrobenthic assemblages - Shelf sediments - Canonical correspondence analysis · Epifauna $\cdot$ Infauna $\cdot$ Marine ecosystems $\cdot$ Bay of Bengal

Resale or republication not permitted without written consent of the publisher

\section{INTRODUCTION}

Benthos represents a major component of the marine environment and plays a vital role in the overall food chain in the sea. Yet, few benthic studies have been conducted in the tropics compared with higher latitudes. The first exploration of tropical continental shelves began off the western edge of Africa in the 1950s (Buchanan 1957, 1958), but there was not a discernible increase in such studies until the mid-1970s (Wade 1972, Parulekar \& Wagh 1975, Ansari et al. 1977, Harkantra et al. 1980, 1982, Parulekar et al. 1982, Warwick \& Ruswahyuni 1987, Da Silva Attolini
\& Santo Tararam 2001, Dittmann 2002). In India, Seshappa (1953) and Kurian (1953) were the first to carry out detailed studies on the bottom fauna off Madras, Malabar and Travancore; since then, a number of (isolated) investigations have been made off both the east and west coasts (Ganapati \& Lakshmana Rao 1959, Radhakrishna \& Ganapati 1969, Kurian 1971, Damodaran 1973, Ansari et al. 1977, Harkantra et al. 1980, 1982, Parulekar et al. 1982, Raman \& Adiseshasai 1989, Raut et al. 2005) albeit with little or no concerted effort to unravel the question of faunal associations at a community level of organization or to identify links to the key environmental factors. The 
present study concerns 2 major scientific investigations (Cruises 171 and 186 of the Fishery and Oceanographic Reseach Vessel [FORV] 'Sagar Sampada') conducted in January 1999 and July 2000 off the Indian northeast shelf; the focus of the study was limited to sub-tidal macrobenthos comprising burrowing organisms (infauna) and surface living fauna (epifauna) retained on a $0.5 \mathrm{~mm}$ mesh. The main objective of this research was to characterize benthic communities (based on species abundance data) and link them to a suite of environmental factors (e.g. depth, sediment texture and organic content, seawater temperature, salinity and dissolved oxygen) measured synchronously at several (24) pre-determined locations (30 to $200 \mathrm{~m}$ ) in shelf waters in the Bay of Bengal.

The Bay of Bengal is unique in many respects. Enormous amounts of freshwater $\left(1.6 \times 10^{12} \mathrm{~m}^{3} \mathrm{yr}^{-1}\right)$ drain into the the sea each year from the hinterland rivers Irravadi, Ganga, Brahmaputra, Mahanadi, Godavari, Krishna and Cauvery (Varkey et al. 1996), and the associated suspended sediment discharge is on the order of $1.4 \times 10^{9} \mathrm{t}$. The inundation by such massive amounts of freshwater renders surface water almost estuarine during the post-monsoon months (September and October) while absolutely marine conditions are present from January to June. In addition, largescale discharges of silt by the rivers reduces the water transparency over large areas in the Bay with a consequent fall in the rate and amount of photosynthesis (Ganapati 1973). An important feature of the Bay of Bengal is the influence of the southwest and northeast monsoons that bring about a complete reversal of the surface current pattern, either clock-wise or counter clock-wise depending on the direction of the wind (LaFond 1957, Varkey et al. 1996, Madhupratap et al. 2003). The annual range of the seawater temperature is 25 to $29^{\circ} \mathrm{C}$, while salinity may vary from 20 to 33 . The isohaline of 34 and above is always outside the Bay (Ganapati 1973). Off Visakhapatnam, the hydrographical conditions are largely influenced by southerly (August-December, salinity 20.79 to 32.97 ) and northerly (January-July, salinity 30.06 to 34.57 ) currents, which run skirting the coast. Upwelling takes place during March-May, leading to annual phytoplankton production mainly dominated by diatoms (>90\%) (Ganapati 1973). There is a marked impoverishment of dissolved oxygen, and an increase in nutrients and salinity at this time of the year compared to offshore waters (LaFond 1957).

A noted geological conformation in the Bay of Bengal is the Ganges Canyon, or 'Swatch of No Ground', which begins in the shallow waters off the Ganges Delta and extends into the continental shelf in a northeast-southwest direction. All along the coast beginning at the 'Swatch of No Ground' down to
Calimere Point, bottom contours of the shelf roughly follow the coastline configuration. The continental shelf is as wide as $160 \mathrm{~km}$ at the head of the Bay, but narrows towards the south $(38 \mathrm{~km})$. In 1963, the Andhra, Mahadevan and Krishna Canyons were discovered off the Andhra coast. An important feature concerning sediments off the Indian east shelf relates to the littoral drift, which is highest during May to August coinciding with strong southwest monsoon (LaFond 1966).

\section{MATERIALS AND METHODS}

Study design and sampling. Two cruises were conducted (January 1999 and July 2000) and altogether 24 stations with 5 transects between $16^{\circ} \mathrm{N}$ (Divi Point) and $20^{\circ} \mathrm{N}$ (Paradip) representing the northeast shelf were examined (Fig. 1, Table 1). At each transect, samples were collected at 30, 50, 100, 150 and $200 \mathrm{~m}$ depth sites depending on the width (narrowness) of the shelf and other factors such as distance between 2 successive stations. For example, off Paradip, where the continental shelf is steep, sampling was restricted to $100 \mathrm{~m}$. On the other hand, when the distance between 2 successive locations exceeded $10 \mathrm{~km}$, an additional station (at $65 \mathrm{~m}$ ) was added (e.g. Visakhapatnam). Both grab and dredge hauls were obtained according to standard protocols (e.g. Holme \& McIntyre 1984). Observations on the physicochemical characteristics of the seawater (temperature, dissolved oxygen, salinity) were made using an onboard CTD (Sea-Bird) facility according to Barnes (1959).

Benthic fauna. A Kahlsico No. 214 WA 250 modified Smith-McIntyre grab $\left(0.1 \mathrm{~m}^{2}\right)$ was used for unit sampling. While it was not always possible to collect replicate hauls from all locations (owing to rough seas), at least 2 grab hauls were made at each site. After taking out a small quantity of sub-sample $(\sim 50 \mathrm{~g})$ for textural analysis, the rest was washed at the onboard facility (sieving platform) using $1 \mathrm{~mm}$ or $0.5 \mathrm{~mm}$ sieves depending on the nature of sediment. For coarse sediments, a $1 \mathrm{~mm}$ sieve was first used. After sieving, all organisms were carefully separated and together with any residual sediment, the samples were fixed in 5 to $7 \%$ (neutral) formaldehyde containing Bengal Rose, labelled and stored for further examination. Prior to sorting (identification), wet weight was determined using a mono-pan electronic balance (AFCOSET ER200A with an accuracy of $0.1 \mathrm{mg}$ ). In order to save inimitable taxa for further examination, biomass $\left(\mathrm{g} \mathrm{m}^{-2}\right)$ was determined as wet weight. All taxa were first segregated into different groups and then identified to specific, generic or other higher levels to the greatest extent possible with the help of standard 


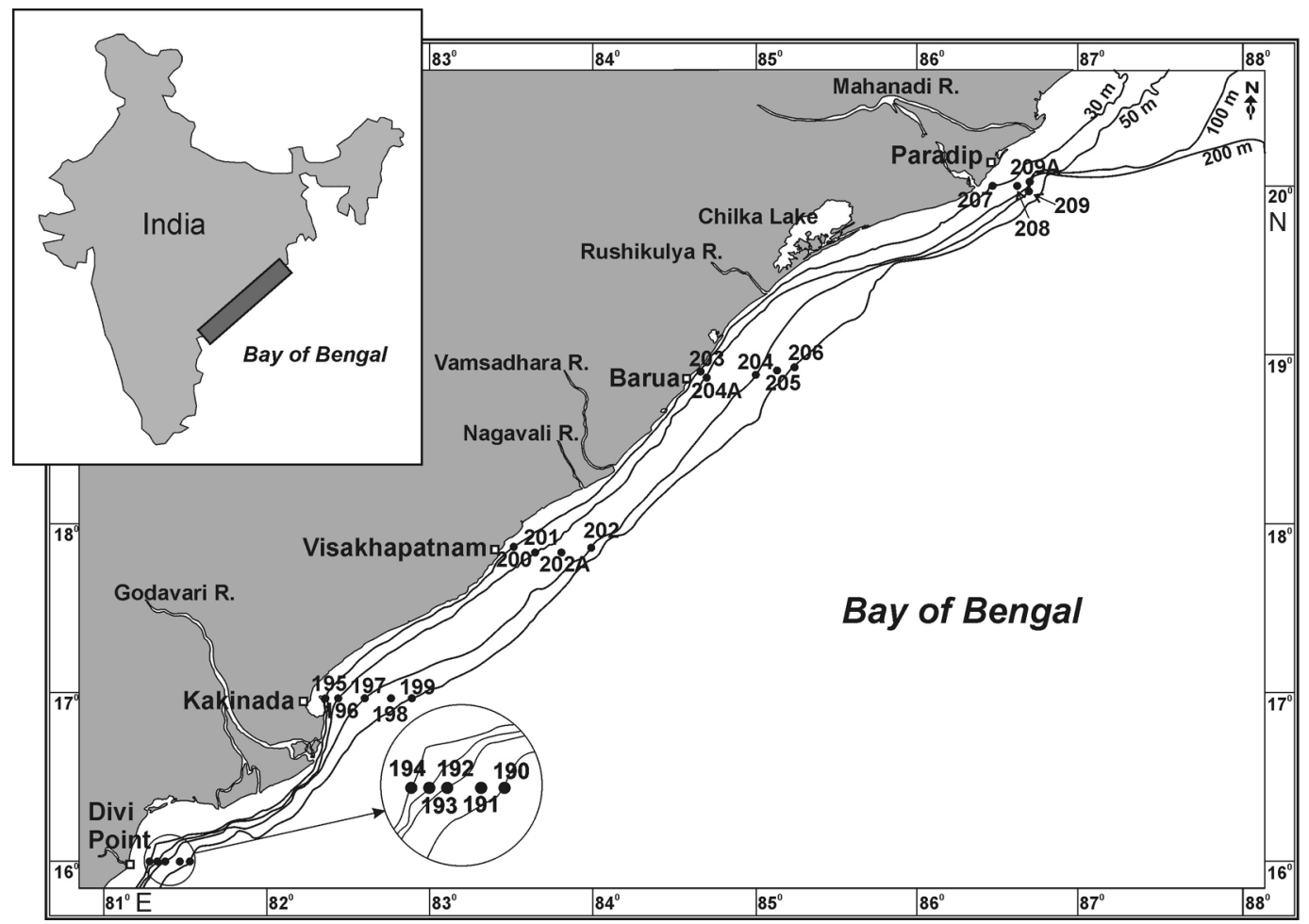

Fig. 1. Macrobenthos of northeast Indian shelf: station locations

Table 1. Benthic macrofauna of northeast Indian shelf: station locations of Cruises 171 and 186 of FORV 'Sagar Sampada'. (Stns 190-209 represent Cruise 171 and Stns 601-664 Cruise 186). -: no data

\begin{tabular}{|c|c|c|c|c|c|c|}
\hline Location & Stn no. & Latitude & Longitude & $\begin{array}{l}\text { Depth } \\
\text { (m) }\end{array}$ & $\begin{array}{c}\text { No. of grab } \\
\text { samples }\end{array}$ & $\begin{array}{l}\text { No. of dredge } \\
\text { samples }\end{array}$ \\
\hline \multirow[t]{5}{*}{ Divi Point } & $194 / 645$ & $15^{\circ} 59^{\prime} 46^{\prime \prime} \mathrm{N}$ & $81^{\circ} 19^{\prime} 48^{\prime \prime} \mathrm{E}$ & 30 & 3 & 1 \\
\hline & $193 / 646$ & $16^{\circ} 00^{\prime} 00^{\prime \prime} \mathrm{N}$ & $81^{\circ} 22^{\prime} 80^{\prime \prime} \mathrm{E}$ & 50 & 3 & 1 \\
\hline & $192 / 647$ & $16^{\circ} 00^{\prime} 00^{\prime \prime} \mathrm{N}$ & $81^{\circ} 25^{\prime} 70^{\prime \prime} \mathrm{E}$ & 100 & 2 & 1 \\
\hline & $191 / 648$ & $16^{\circ} 00^{\prime} 00^{\prime \prime} \mathrm{N}$ & $81^{\circ} 27^{\prime} 70^{\prime \prime} \mathrm{E}$ & 150 & 2 & - \\
\hline & $190 / 649$ & $16^{\circ} 00^{\prime} 50^{\prime \prime} \mathrm{N}$ & $81^{\circ} 29^{\prime} 30^{\prime \prime} \mathrm{E}$ & 200 & 2 & - \\
\hline \multirow[t]{5}{*}{ Kakinada } & $195 / 652$ & $17^{\circ} 00^{\prime} 00^{\prime \prime} \mathrm{N}$ & $82^{\circ} 26^{\prime} 40^{\prime \prime} \mathrm{E}$ & 30 & 4 & 2 \\
\hline & $196 / 653$ & $17^{\circ} 00^{\prime} 00^{\prime \prime} \mathrm{N}$ & $82^{\circ} 31^{\prime} 00^{\prime \prime} \mathrm{E}$ & 50 & 3 & 2 \\
\hline & $197 / 654$ & $17^{\circ} 00^{\prime} 00^{\prime \prime} \mathrm{N}$ & $82^{\circ} 43^{\prime} 90^{\prime \prime} \mathrm{E}$ & 100 & 2 & 2 \\
\hline & $198 / 655$ & $17^{\circ} 00^{\prime} 02^{\prime \prime} \mathrm{N}$ & $82^{\circ} 50^{\prime} 86^{\prime \prime} \mathrm{E}$ & 150 & 2 & - \\
\hline & $199 / 656$ & $17^{\circ} 00^{\prime} 09^{\prime \prime} \mathrm{N}$ & $82^{\circ} 58^{\prime} 20^{\prime \prime} \mathrm{E}$ & 200 & 2 & - \\
\hline \multirow[t]{5}{*}{ Visakhapatnam } & $200 / 664$ & $17^{\circ} 53^{\prime} 00^{\prime \prime} \mathrm{N}$ & $83^{\circ} 35^{\prime} 70^{\prime \prime} \mathrm{E}$ & 30 & 3 & 2 \\
\hline & $201 / 663$ & $17^{\circ} 52^{\prime} 20^{\prime \prime} \mathrm{N}$ & $83^{\circ} 41^{\prime} 30^{\prime \prime} \mathrm{E}$ & 50 & 2 & 2 \\
\hline & 202A/662 & $17^{\circ} 50^{\prime} 74^{\prime \prime} \mathrm{N}$ & $83^{\circ} 49^{\prime} 59^{\prime \prime} \mathrm{E}$ & 65 & 2 & 2 \\
\hline & 661 & $17^{\circ} 51^{\prime} 26^{\prime \prime} \mathrm{N}$ & $83^{\circ} 57^{\prime} 02^{\prime \prime} \mathrm{E}$ & 65 & 2 & 1 \\
\hline & $202 / 660$ & $17^{\circ} 51^{\prime} 00^{\prime \prime} \mathrm{N}$ & $84^{\circ} 00^{\prime} 90^{\prime \prime} \mathrm{E}$ & 100 & 3 & 1 \\
\hline \multirow[t]{5}{*}{ Barua } & 203/203A/601 & $18^{\circ} 59^{\prime} 80^{\prime \prime} \mathrm{N}$ & $84^{\circ} 46^{\prime} 10^{\prime \prime} \mathrm{E}$ & 30 & 4 & 1 \\
\hline & $204 \mathrm{~A} / 602$ & $19^{\circ} 00^{\prime} 00^{\prime \prime} \mathrm{N}$ & $84^{\circ} 48^{\prime} 40^{\prime \prime} \mathrm{E}$ & 50 & 3 & 2 \\
\hline & $204 / 603$ & $19^{\circ} 00^{\prime} 06^{\prime \prime} \mathrm{N}$ & $85^{\circ} 04^{\prime} 19^{\prime \prime} \mathrm{E}$ & 100 & 3 & 2 \\
\hline & $205 / 604$ & $19^{\circ} 00^{\prime} 19^{\prime \prime} \mathrm{N}$ & $85^{\circ} 11^{\prime} 30^{\prime \prime} \mathrm{E}$ & 150 & 2 & 1 \\
\hline & $206 / 605$ & $19^{\circ} 00^{\prime} 10^{\prime \prime} \mathrm{N}$ & $85^{\circ} 17^{\prime} 40^{\prime \prime} \mathrm{E}$ & 200 & 2 & 1 \\
\hline \multirow[t]{4}{*}{ Paradip } & $207 / 608$ & $20^{\circ} 00^{\prime} 00^{\prime \prime} \mathrm{N}$ & $86^{\circ} 33^{\prime} 20^{\prime \prime} \mathrm{E}$ & 30 & 3 & 2 \\
\hline & $208 / 609$ & $20^{\circ} 00^{\prime} 00^{\prime \prime} \mathrm{N}$ & $86^{\circ} 41^{\prime} 00^{\prime \prime} \mathrm{E}$ & 40 & 2 & 2 \\
\hline & $209 \mathrm{~A} / 610$ & $20^{\circ} 00^{\prime} 02^{\prime \prime} \mathrm{N}$ & $86^{\circ} 45^{\prime} 80^{\prime \prime} \mathrm{E}$ & 50 & 3 & 2 \\
\hline & $209 / 611$ & $19^{\circ} 57^{\prime} 27^{\prime \prime} \mathrm{N}$ & $86^{\circ} 46^{\prime} 18^{\prime \prime} \mathrm{E}$ & 100 & 3 & 2 \\
\hline
\end{tabular}


taxonomic references (e.g. Polychaeta: Fauvel 1953, Day 1967; Mollusca: Subba Rao et al. 1991). The organisms were later counted under a stereoscopic microscope (Olympus SZ40, 40× magnification) and abundance was expressed as ind. $\mathrm{m}^{-2}$.

Epifauna were collected using a naturalist's dredge, a metal $40 \times 40 \mathrm{~cm}$ frame fitted with a nylon mesh $\left(1.0 \mathrm{~cm}^{2}\right)$ and weighted enough to reach the sea bottom. At each location, the dredge was operated for varying times ( 10 to $45 \mathrm{~min}$ ) depending on the location (depth), nature of the bottom, etc. Onboard, all organisms were washed with seawater in a large metal tray and after separation the animals were carefully transferred into polythene containers, labelled and preserved in $7 \%$ formaldehyde/methylated ethanol for later study. While sorting, only live material was picked. In the laboratory, these organisms were counted (ind. haul ${ }^{-1}$ ) under suitable magnification $(4 \times)$.

Sediment texture. Sediments (sub-samples) were oven-dried $\left(60^{\circ} \mathrm{C}\right)$ onboard and stored until further analysis. In the laboratory, the samples were subjected to sieving and pipette analysis according to standard procedures (Krumbein \& Pettijohn 1938, Holme \& McIntyre 1984). In each case, the proportion of sand, silt and clay (\%) was calculated and values plotted on triangular graphs according to nomenclature suggested by Sheppard (1954). Organic matter was estimated by the wet oxidation method of Walkley-Black but as modified by Gaudette et al. (1974).

Data analysis. Univariate measures included species richness Shannon-Wiener diversity $\left(H^{\prime} \log _{\mathrm{e}}\right)$ and evenness $\left(J^{\prime}\right)$. Multivariate analysis consisted of estimating Bray-Curtis similarity after suitable transformation of sample abundance data. The similarity matrix was subjected to both clustering (hierarchical agglomerative method using group-average linking) and ordination (non-metric multidimensional scaling, MDS) using PRIMER 5.1 (Clarke \& Gorley 2001). Significance tests of sample groupings were made using the ANOSIM (1-way) randomization test. The contribution of each species to groupings noticed in the cluster and ordination analysis was examined using SIMPER (similarity percentages) implemented in PRIMER (Clarke \& Warwick 1994) to quantify percentage contribution of each species to similarity within each group (i.e. characteristic) of samples and to dissimilarity between different groups. Other routines (e.g. BVSTEP), namely stepwise searches of combinations of species considered to be ultimately responsible for the observed pattern in the biotic assemblages, were also carried out using PRIMER. Canonical Correspondence Analysis, (CCA) (CANOCO 4.53, ter Braak 1986, ter Braak \& Šmilauer 2002) was performed to evaluate possible correlations between environmental variables, macrobenthic species and variance in site pattern, using a form of stepwise regression. A Monte Carlo permutation test (unrestricted) was used to determine the significance of species-environment relationships.

\section{RESULTS}

Spatially there were large differences in sediment structure (analysis of similarities, ANOSIM, Global R = 0.187 , significance $p=0.019$ ), the predominant textural class in several cases (27 samples) being clayey silt followed by silty clay (16). At most sites, the sediments consisted of relatively soft (mud) substrata even in shallow areas $(<30 \mathrm{~m})$ except off Visakhapatnam, where they typically represented 'sand' and differed markedly from others $(R=0.483, p=0.004)$. Sediment organic matter also varied appreciably (Global $\mathrm{R}=$ $0.24, \mathrm{p}=0.001)$ in relation to depth and nature of substratum (Table 2, Fig. 2).

In total 169 macrobenthic species represented by 15 diverse taxa were encountered, of which gastropods, bivalves, polychaetes and decapods formed by far the most important groups. Among the epifauna, gastropods constituted a more diverse group (49 species) followed by crustaceans (34), polychaetes (26) and bivalves (25). Polychaetes dominated the infauna (60 species) and contributed numerically up to $~ 65 \%$ of the population. The spionid Prionospio pinnata was a

Table 2. Sediment characteristics of northeast Indian shelf, Cruises 171 and 186. Data presented as mean \pm SD (range). MPD: mean particle diameter

\begin{tabular}{|lccccc|}
\hline Characteristic & \multirow{2}{*}{$30-50 \mathrm{~m}$} & $51-75 \mathrm{~m}$ & $76-100 \mathrm{~m}$ & $101-150 \mathrm{~m}$ & $>150 \mathrm{~m}$ \\
\hline Sand $(\%)$ & $27.2 \pm 31.0(1.1-90.2)$ & $9.4 \pm 5.1(4.0-14.1)$ & $20.8 \pm 29.1(0.8-92.2)$ & $2.5 \pm 1.2(1.2-4.7)$ & $1.0 \pm 0.9(0.1-2.5)$ \\
Silt $(\%)$ & $35.0 \pm 17.3(6.2-61.6)$ & $43.2 \pm 15.2(28.2-62.5)$ & $45.6 \pm 24.7(4.0-87.5)$ & $55.4 \pm 17.5(32.1-79.3)$ & $55.0 \pm 11.6(35.0-67.2)$ \\
Clay $(\%)$ & $37.8 \pm 18.3(3.6-66.6)$ & $47.4 \pm 17.3(23.4-21.7)$ & $33.6 \pm 18.7(3.9-70.4)$ & $42.0 \pm 18.2(18.2-65.9)$ & $43.9 \pm 12.1(31.8-64.7)$ \\
Organic & $2.5 \pm 0.2(0.7-4.2)$ & $3.2 \pm 0.7(2.2-3.8)$ & $3.4 \pm 0.9(2.0-4.9)$ & $4.2 \pm 0.7(2.9-4.9)$ & $4.8 \pm 1.3(3.1-6.1)$ \\
$\quad$ & & & & & \\
matter $(\%)$ & & & & & \\
Mean size $(\mu \mathrm{m})$ & $49.4 \pm 97.1(1.5-435)$ & $6.2 \pm 5.0(2.5-13.6)$ & $26.9 \pm 55.2(1.2-196)$ & $5.2 \pm 3.0(1.8-9.7)$ & $4.2 \pm 1.5(2.5-6.1)$ \\
MPD $(\mu \mathrm{m})$ & $92.5 \pm 160(0.5-500)$ & $7.5 \pm 7.9(2.2-19.2)$ & $37.8 \pm 66.7(0.8-196)$ & $5.7 \pm 2.7(1.9-9.8)$ & $5.2 \pm 1.8(2.2-7.3)$ \\
\hline
\end{tabular}




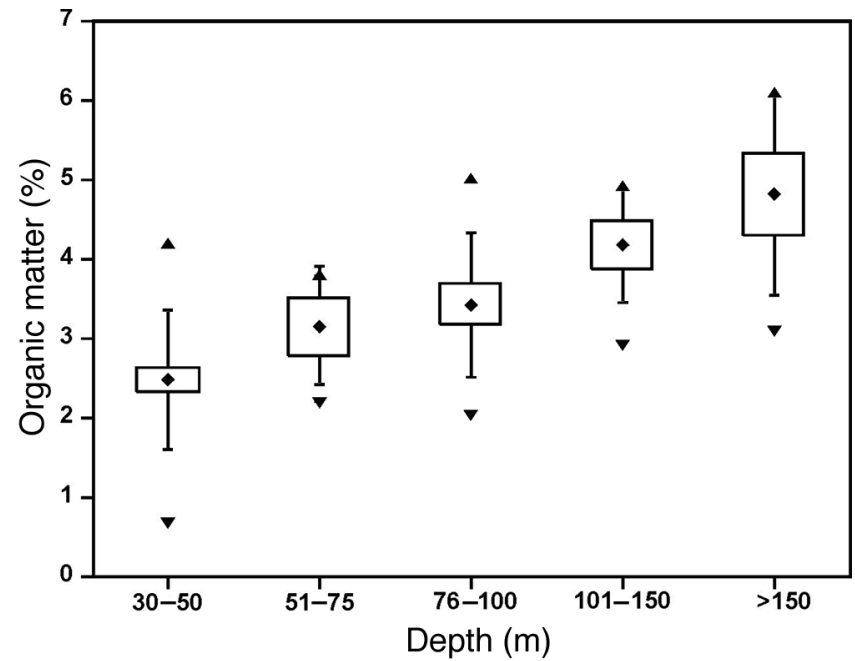

Fig. 2. Box-and-whisker plots of sediment organic matter (\%) for different depth classes. Data presented as mean $(\bullet) \pm 1 \mathrm{SE}$ (boxes) and $\pm 1 \mathrm{SD}$ (whiskers). $\mathbf{\nabla}$ : minimum; $\mathbf{\Delta}$ : maximum

distinct inhabitant at several locations, accounting for $7.1 \%$ of the total numbers. Amphipods contributed up to $25 \%$ numerically. The eunicid Diopatra neapolitana appeared regularly among dredge collections and accounted for a sizable population (12.6\%). There was an array of gastropods (45 species) in the dredge hauls of which Nassaria acuminata, N. nivea, Nassarius variegatus, Turricula sp., Conus inscriptus, Tibia delicatula, Ficus gracilis, Bursa echinata and Agaronia nebulosa were predominant (6.9 to $11.9 \%$ ). Bivalves consisted of 22 species and Modiolus phillipinarum,
Mactra mera, Tellina robusta, Macoma sp. and the mytilid Amygdalum watsoni were important (2.5 to $5.6 \%$ ). In addition, there were ophiuroids (Amphioplus depressus), echinoids (Clypeaster rarispinus, Echinodiscus auritus), a holothurid (Acaudina molpadioides), and a brachiopod (Lingula sp.).

Classification analyses (using Bray-Curtis similarity) followed by an ordination through MDS on benthos abundance data (ind. haul ${ }^{-1} \mathrm{~m}^{-2}$ ) independently for epifauna (156 species) and infauna (86 species) were undertaken. Figs. 3 to 6 display results of hierarchical clustering, using group average linking on species abundance data representing varying depth categories $(30-50,51-75,76-100,101-150$, and $>150 \mathrm{~m})$. Bray-Curtis similarities were calculated on square root transformed abundance of epifauna. From the resulting dendrogram (Fig. 3), it was possible to classify the sites into 4 groups (depth categories) determined at $\sim 10 \%$ similarity. These consisted of Group A (19) samples representing 30 to $50 \mathrm{~m}$; Group B (3) samples, 51 to $75 \mathrm{~m}$; Group C (8) samples, 76 to $100 \mathrm{~m}$; and, Group D (2) samples at $>100 \mathrm{~m}$. The dendrogram provided a sequence of groups confirmed by the MDS plot (Fig. 4a). A corresponding cluster of these sites/samples superimposed with depth categories is also presented (Fig. 4b).

On the infauna datum, 3 groups of assemblages (1 outlier) each representing a depth category could be recognized at $30 \%$ similarity (Fig. 5). These consisted of Group A (37 samples) representing 30 to $75 \mathrm{~m}$, Group B (13) samples from 76 to 100 m, and Group C (11) samples corresponding to $>100 \mathrm{~m}$. The corre-

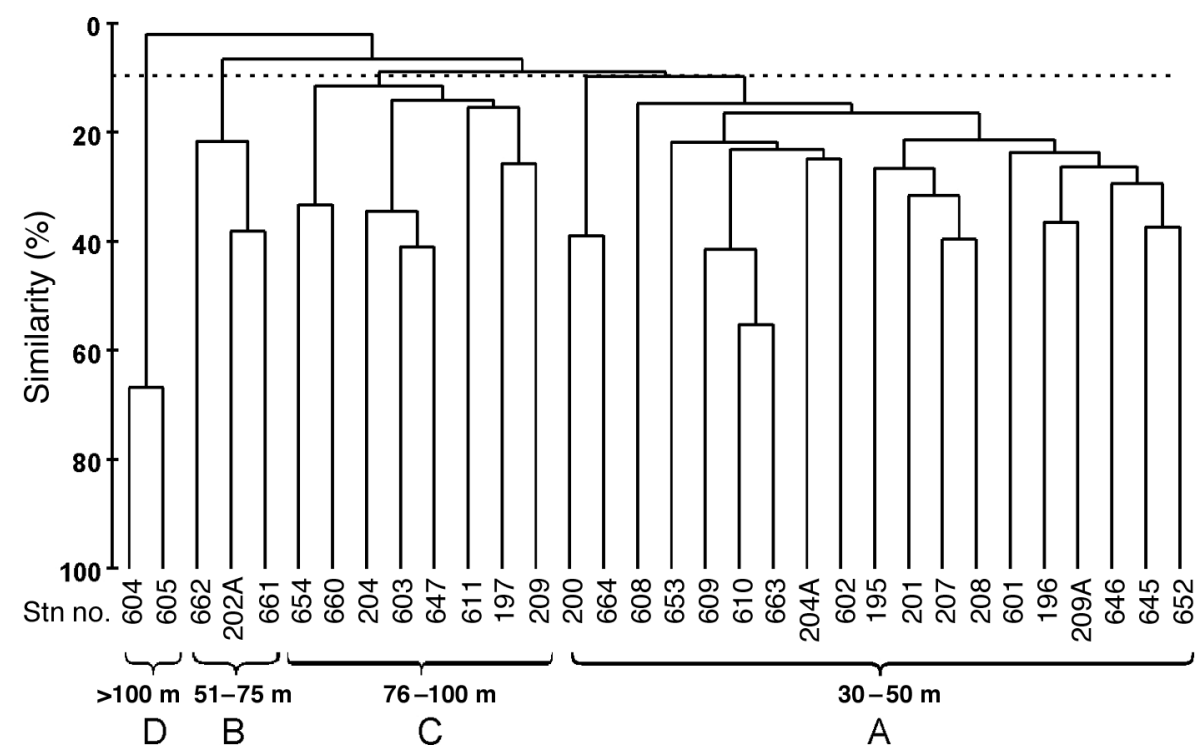

Fig. 3. Epibenthos of the northeast Indian shelf. Dendrogram for hierarchical clustering of 32 dredge samples using groupaverage linking of Bray-Curtis similarities (square root transformed abundance data). A to D: groups (depth categories) determined at $10 \%$ similarity (dashed line) 

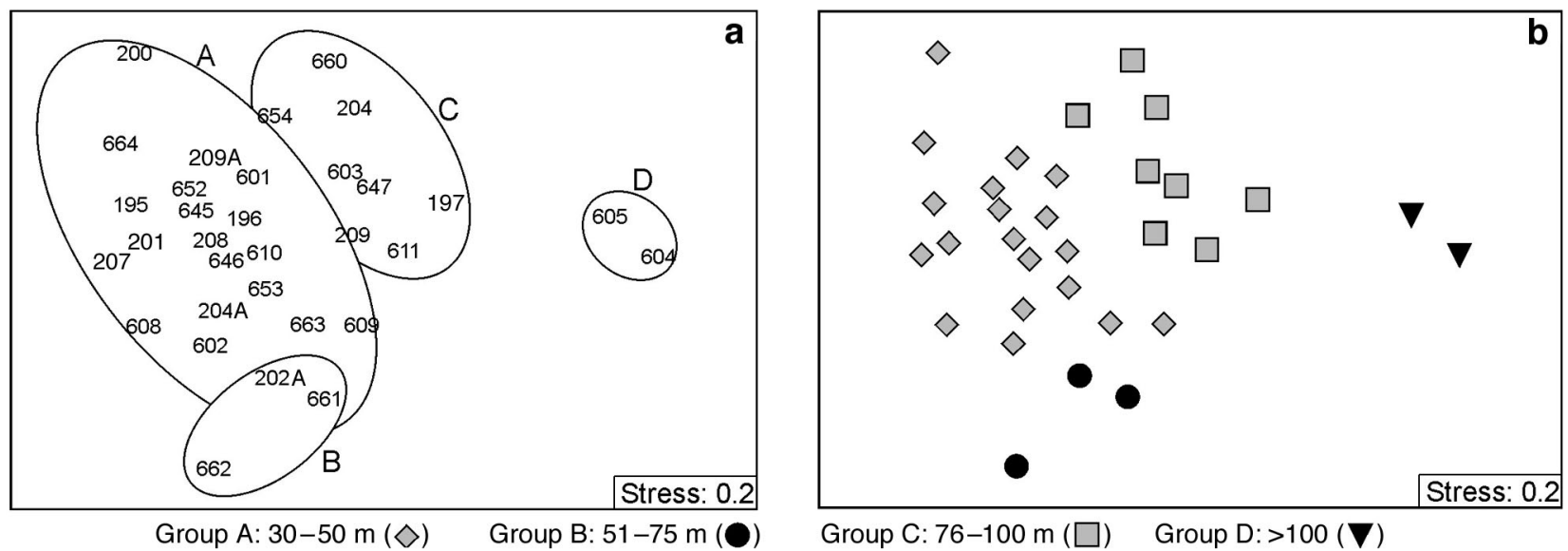

Fig. 4. Epibenthos of the northeast Indian shelf. (a) Multidimensional scaling (MDS) plot for 32 samples. (b) Plot superimposed with depth classes

sponding MDS plots (Fig. 6) confirmed the observed findings.

Epifaunal density (dredge collections) varied markedly ( 3 to 160 ind. haul ${ }^{-1}$ ) in relation to depth (ANOSIM Global $\mathrm{R}=0.746, \mathrm{p}<0.05$ ). The 30 to $50 \mathrm{~m}$ sites yielded the richest fauna (mean density 51 ind. haul ${ }^{-1}$ ), contributing up to $71.82 \%$ of total population. Faunal abundance, however, decreased at 51 to $100 \mathrm{~m}$ (mean 37 ind. haul ${ }^{-1}$ ) and $>100 \mathrm{~m}$ (28 ind. haul ${ }^{-1}$ ) (Fig. $7 \mathrm{~b}$, Table 3 ). Spatially $\left(16^{\circ}\right.$ to $20^{\circ} \mathrm{N}$ ), benthos densities were highest (60 ind. haul $\left.^{-1}\right)$ off Paradip $\left(20^{\circ} \mathrm{N}, 86^{\circ} 33^{\prime}\right.$ to $\left.46^{\prime} \mathrm{E}\right)$ and contributed up to $35.4 \%$ of the total population. Differing sedimentary setting (e.g. ratio of sand, silt and clay), proximity to river inflows (affecting sediment deposition) and local hydrographical conditions (e.g. primary production) appeared important (e.g. Parulekar et al. 1982, Alongi 1990). Close to where the River Hooghly joins the Bay of Bengal, the organically rich sediments supported rich benthos as a result of massive river inflows draining into the Gangetic delta (Harkantra et al. 1982).

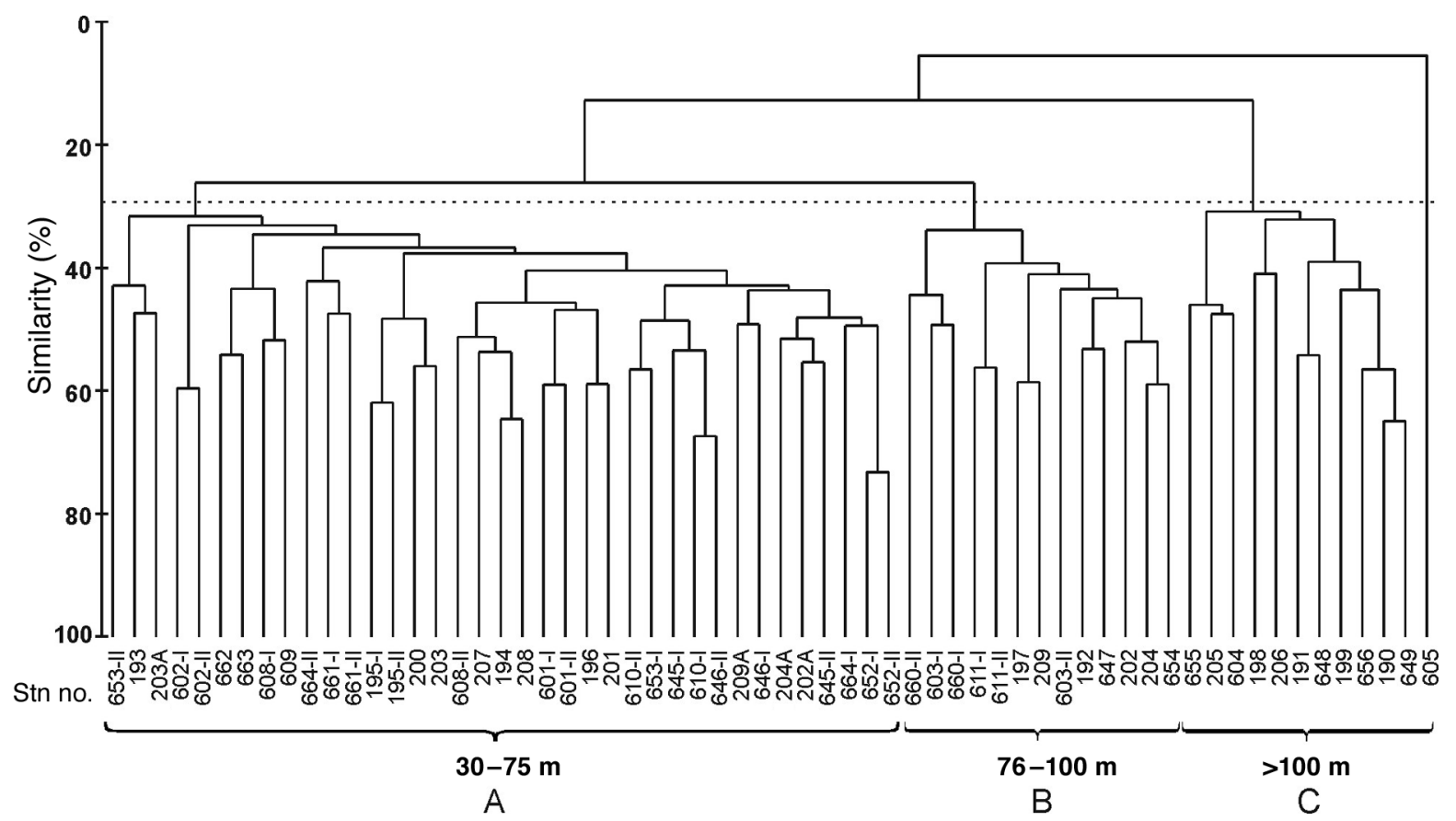

Fig. 5. Infauna of the northeast Indian shelf. Dendrogram for hierarchical clustering of 62 grab samples using group-average linking of Bray-Curtis similarities (square root transformed abundance data). A to C: groups (depth categories) determined at $30 \%$ similarity (dashed line) 

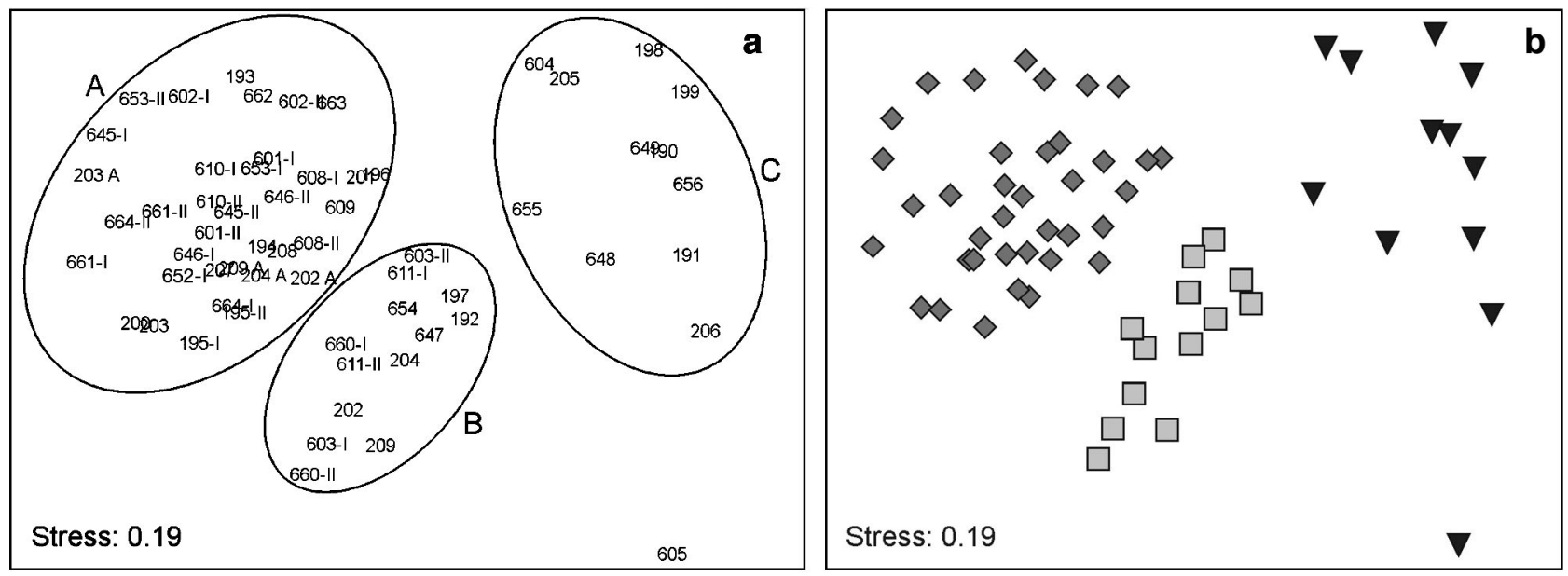

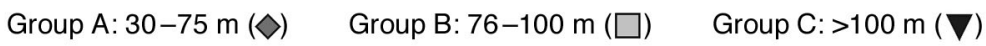

Fig. 6. Infauna of the northeast Indian shelf. (a) Multidimensional scaling (MDS) plot for 62 samples. (b) Plot superimposed with depth classes

Infaunal densities (grab hauls) varied (30 to 2460 ind. $\mathrm{m}^{-2}$ ) significantly depth-wise (ANOSIM Global $\mathrm{R}=$ $0.782, \mathrm{p}=0.001$ ). The 30 to $50 \mathrm{~m}$ sites supported up to $60.8 \%$ of the total population numerically (mean density $775 \pm 103$ ind $\mathrm{m}^{-2}$ ), the predominant taxa being amphipods (17.5\%, Fig. 8b, Table 4). Between the depths 51 and $75 \mathrm{~m}$, mean abundance was $1080 \pm 292$ ind. $\mathrm{m}^{-2}$.
Numbers, however, swiftly dwindled with depth. North to south infaunal densities remained highest (mean 888 ind. $\mathrm{m}^{-2}$ ) off Visakhapatnam $\left(17^{\circ} 53^{\prime} 00^{\prime \prime} \mathrm{N}\right)$.

Biomass (grab hauls: mean wet weight $\mathrm{g} \mathrm{m}^{-2}$ ) was highest $(6.941 \pm 4.8)$ at 51 to $75 \mathrm{~m}$, where large-sized Eunice sp. $\left(\sim 80\right.$ ind. $\left.\mathrm{m}^{-2}\right)$ contributed to the bulk and the biomass was the lowest $(1.078 \pm 1.2)$ further
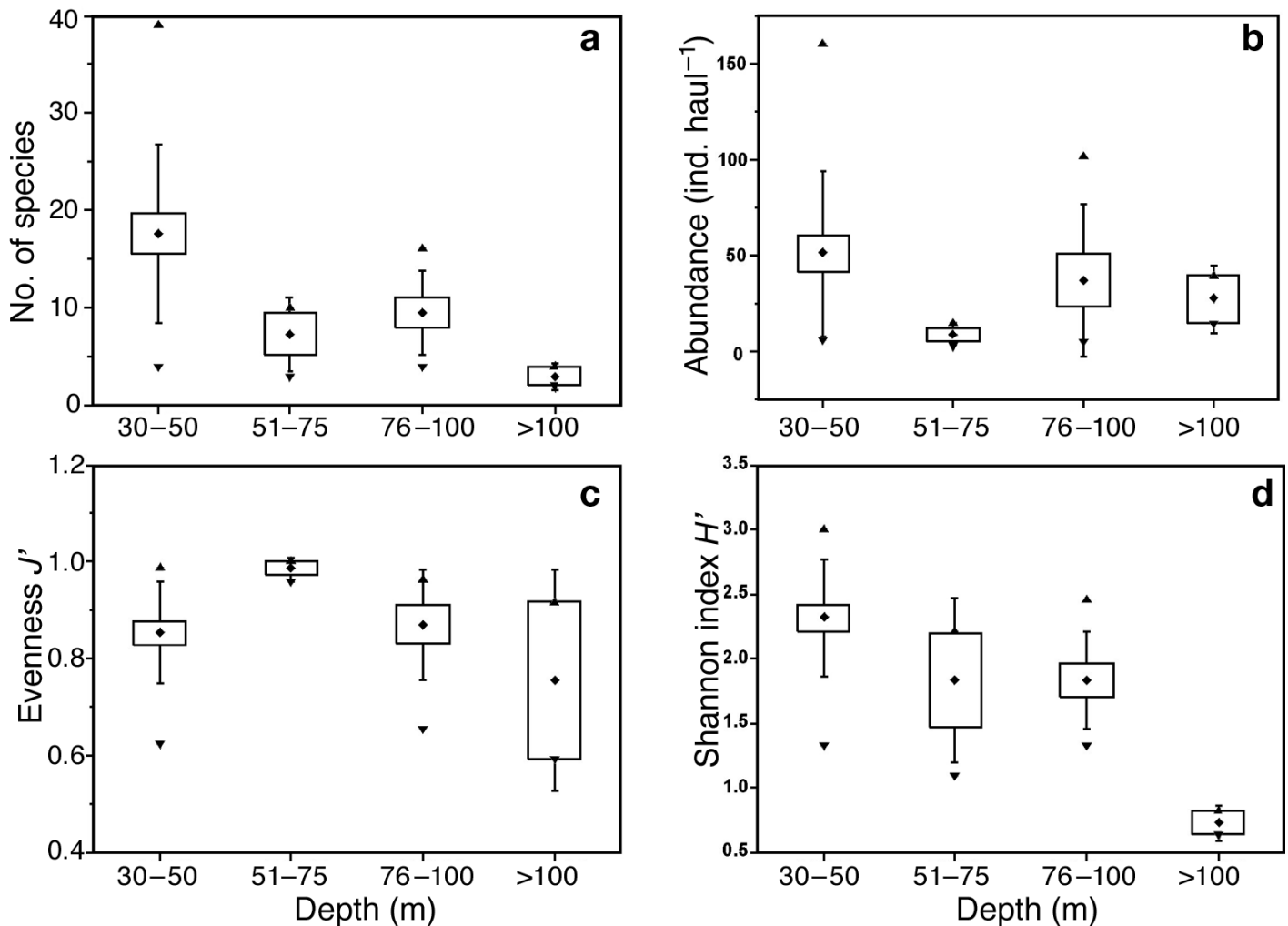

Fig. 7. Univariate measures for macrobenthic epifauna of the northeast Indian shelf. (a) No. of species; (b) abundance; (c) evenness $J^{\prime}{ }_{i}(\mathrm{~d})$ Shannon-Wiener index $H^{\prime}$. Data presented as mean $(\bullet) \pm 1$ SE (boxes) and \pm 1 SD (whiskers). $\mathbf{\nabla}:$ minimum; $\mathbf{\Delta}:$ maximum 
Table 3. Distribution of important epifaunal species (ind. haul ${ }^{-1}$ ) at different depths on the northeast Indian shelf (identified through SIMPER/ BVSTEP analyses). Abbrev.: abbreviation used in Fig. 10b. Data presented as mean \pm SD (range). -: not found in this depth range

\begin{tabular}{|c|c|c|c|c|c|}
\hline Species & Abbrev. & $30-50 \mathrm{~m}$ & $51-75 \mathrm{~m}$ & $76-100 \mathrm{~m}$ & $>100 \mathrm{~m}$ \\
\hline Virgularia sp. & Virg & - & - & $0.75 \pm 0.31(0-2)$ & - \\
\hline Panthalis sp. & Panth & $2.00 \pm 0.92(1-17)$ & $0.33 \pm 0.33(0-1)$ & $1.5 \pm 0.98(0-8)$ & - \\
\hline Eunice indica & Eun ind & $6.80 \pm 3.48(1-18)$ & - & - & - \\
\hline Diopatra neapolitana & Dio nea & $5.74 \pm 2.56(0-35)$ & - & $7.63 \pm 5.95(1-48)$ & - \\
\hline Maldanidae sp. 1 & Mal sp. 1 & $1.32 \pm 0.74(1-14)$ & $0.33 \pm 0.33(0-1)$ & - & - \\
\hline Maldanidae sp. 2 & & - & - & $2.67 \pm 0.88(0-4)$ & - \\
\hline Flabelligera sp. & & - & $0.33 \pm 0.33(0-1)$ & $0.50 \pm 0.38(1-3)$ & - \\
\hline Terebellidae & Tereb & $0.95 \pm 0.53(1-10)$ & - & $0.25 \pm 0.25(1-2)$ & - \\
\hline Pista sp. & & $0.89 \pm 0.79(1-15)$ & - & - & - \\
\hline Oratosquilla sp. & Orato & - & $0.67 \pm 0.67(1-2)$ & $0.63 \pm 0.26(12)$ & - \\
\hline Parapenaeus sp. & & - & - & $1.25 \pm 0.86(1-7)$ & - \\
\hline Polychelid lobsters & Polychel & - & - & $3.63 \pm 3.48(0-28)$ & - \\
\hline Raninoides serratifrons & Ran ser & $0.58 \pm 0.27(1-5)$ & $1.00 \pm 0.58(1-2)$ & - & - \\
\hline Calappa lophos & & $0.21 \pm 0.16(1-3)$ & - & - & - \\
\hline Charybdis sp. & Char & $6.89 \pm 3.70(1-70)$ & - & $0.38 \pm 0.18(0-1)$ & - \\
\hline Liagore sp. & Liag & $0.16 \pm 0.12(1-2)$ & $1 \pm 0(1)$ & - & - \\
\hline Majidae & Majid & - & - & $1.00 \pm 0.68(1-5)$ & - \\
\hline Tibia delicatula & Tib deli & - & - & $0.50 \pm 0.19(0-1)$ & $6.00 \pm 1.00(5-7)$ \\
\hline Natica vitellus & Nat vit & - & $0.33 \pm 0.33(0-1)$ & $0.75 \pm 0.41(1-3)$ & - \\
\hline Nassarius variegatus & & $1.05 \pm 0.52(1-7)$ & - & - & - \\
\hline Gemmula speciosa & & $0.21 \pm 0.12(1-2)$ & $0.33 \pm 0.33(0-1)$ & - & - \\
\hline Lophiotoma indica & Loph ind & 1 & $2.00 \pm 1.00(0-3)$ & - & - \\
\hline Conus inscriptus & Con ins & $0.89 \pm 0.45(1-8)$ & $0.67 \pm 0.33(0-1)$ & - & - \\
\hline Terebra collumelaris & & $0.32 \pm 0.15(1-2)$ & - & - & - \\
\hline Amygdalum watsoni & Amy wat & $0.05 \pm 0.05(0-1)$ & - & - & $19.50 \pm 9.50(10-29)$ \\
\hline Amphioplus depressus & Amp dep & $2.32 \pm 0.66(1-12)$ & - & $1.25 \pm 0.37(1-3)$ & - \\
\hline Clypeaster rarispinus & Clyp rar & $0.84 \pm 0.41(1-7)$ & $0.33 \pm 0.33(0-1)$ & $1.25 \pm 1.25(1-10)$ & - \\
\hline Echinodiscus auritus & & $0.21 \pm 0.16(1-3)$ & - & - & - \\
\hline Sipunculida & & $0.84 \pm 0.53(1-10)$ & - & - & - \\
\hline Pleuronectidae & Pleuro & - & $0.67 \pm 0.67(1-2)$ & $0.38 \pm 0.26(1-2)$ & $0.50 \pm 0.50(0-1)$ \\
\hline Overall abundance & & $51 \pm 10(6-160)$ & $9 \pm 4(3-15)$ & $37 \pm 14(5-102)$ & $28 \pm 13(15-40)$ \\
\hline
\end{tabular}
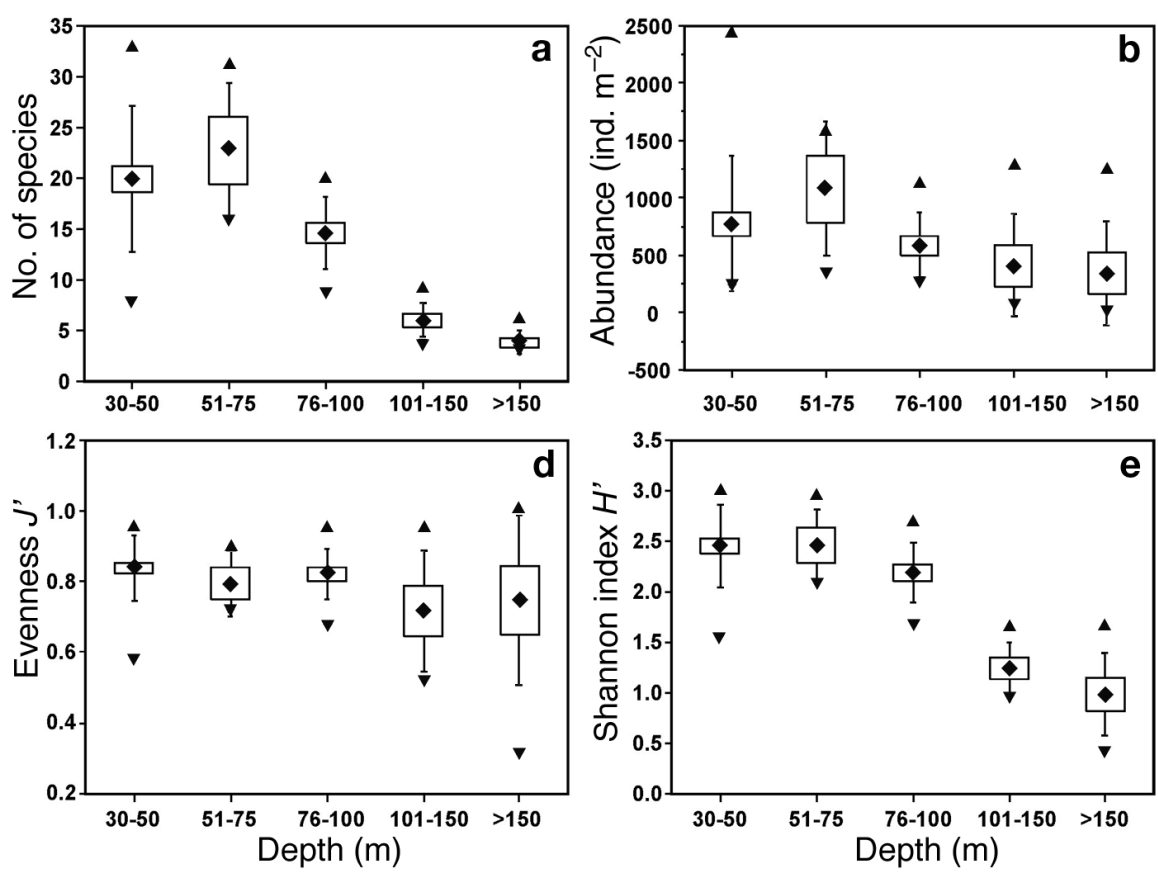

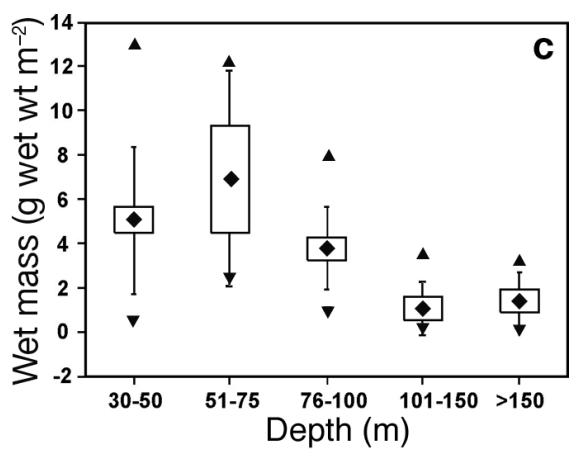

Fig. 8. Univariate measures for macrobenthic infauna of the northeast Indian shelf. (a) No. of species; (b) abundance; (c) biomass; (d) evenness $J^{\prime} ;$ (e) ShannonWiener index $H^{\prime}$. Data presented as mean $(\bullet) \pm 1 \mathrm{SE}$ (boxes) and $\pm 1 \mathrm{SD}$ (whiskers). v: minimum; $\mathbf{\Delta}$ : maximum 
Table 4. Distribution of important infaunal species (ind. $\mathrm{m}^{-2}$ ) at different depths on the northeast Indian shelf (identified through SIMPER/ BVSTEP analyses). Abbrev.: abbreviation used in Fig. 11b. Data presented as mean \pm SE (range). -: not found in this depth range

\begin{tabular}{|lcccc|}
\hline Species & Abbrev. & 30-75 m & $76-100 \mathrm{~m}$ & $>100 \mathrm{~m}$ \\
\hline Chloeia rosea & Chl ros & $39.7 \pm 17.2(10-640)$ & $36.2 \pm 11.0(10-130)$ & $1.7 \pm 1.7(10-20)$ \\
Ancistrosyllis parva & Anc par & $13.0 \pm 2.7(10-60)$ & $73.1 \pm 30.8(10-390)$ & $4.2 \pm 2.3(10-20)$ \\
Nereis sp. & Ner & $10.5 \pm 3.8(10-100)$ & $6.2 \pm 2.1(0-20)$ & $0.8 \pm 0.8(0-10)$ \\
Nephtys sp. & Neph & $45.4 \pm 6.9(10-210)$ & $125.4 \pm 312.0(0-420)$ & $1.7 \pm 1.1(0-10)$ \\
Lumbrineris sp. 1 & Lum sp. 1 & $14.6 \pm 2.9(10-60)$ & $3.1 \pm 1.3(0-10)$ & - \\
Prionospio sp. 2 & Prio sp. 2 & $9.7 \pm 3.9(10-130)$ & $7.7 \pm 2.3(10-20)$ & $86.7 \pm 43.5(10-530)$ \\
Spionidae sp. 1 & Spi sp. 1 & $17.0 \pm 5.8(10-200)$ & $0.7 \pm 0.7(0-10)$ & $0.8 \pm 0.8(0-10)$ \\
Spionidae sp. 3 & Spi sp. 3 & $7.3 \pm 2.6(10-60)$ & $49.2 \pm 17.3(0-200)$ & - \\
Magelona sp. & Mage & $19.2 \pm 4.9(0-140)$ & $13.9 \pm 7.7(10-100)$ & $4.2 \pm 3.4(10-40)$ \\
Cirratulidae sp. 1 & Cirs sp. 1 & $43 \pm 8.6(10-250)$ & $53.1 \pm 15.5(10-150)$ & $174.2 \pm 69.1(10-700)$ \\
Cossura coasta & Cos coas & $10.8 \pm 2.4(10-70)$ & $44.6 \pm 18.4(10-230)$ & - \\
Mediomastus sp. & Medio & $19.2 \pm 8.2(10-260)$ & $2.3 \pm 1.7(10-20)$ & - \\
Notomastus sp. & Noto & $16.8 \pm 4.3(10-100)$ & $4.6 \pm 4.6(10-60)$ & - \\
Ampelisca sp. & Ampel & $211.1 \pm 43.1(10-1390)$ & - & - \\
Maera sp. & Maer & $25.7 \pm 5.5(10-140)$ & $1.5 \pm 1.5(10-20)$ & $7.8 \pm 49.0(10-560)$ \\
Corophium sp. & Coro & $1.4 \pm 1.4(10-50)$ & $22.3 \pm 5.0(10-70)$ & $8.3 \pm 3.2(10-40)$ \\
Nemertean & Neme & $10.5 \pm 1.9(10-40)$ & $6.2 \pm 3.1(10-30)$ & $379 \pm 124(30-1280)$ \\
Overall abundance & & $808 \pm 97(230-2460)$ & $586 \pm 82(290-1140)$ & \\
\hline
\end{tabular}

offshore at 101 to $150 \mathrm{~m}$ (Fig. 8c). Parulekar et al. (1982) presented a comparative account of benthic biomass between the Bay of Bengal and the Arabian Sea along with the Andaman and Lakshadweep regions, and noticed a variation between 0.01 and $601 \mathrm{~g} \mathrm{~m}^{-2}$, which was significantly higher in the Arabian Sea (mean $\left.17.6 \mathrm{~g} \mathrm{~m}^{-2}\right)$ than in the Bay of Bengal $\left(5.5 \mathrm{~g} \mathrm{~m}^{-2}\right)$, the Andaman $\left(7.3 \mathrm{~g} \mathrm{~m}^{-2}\right)$ or Lakshadweep Seas $(0.7 \mathrm{~g}$ $\mathrm{m}^{-2}$ ). T. V. Joydas (pers. comm.) carried out a detailed investigation on benthos productivity for several locations on the west coast of India and noticed that biomass often exceeded $5.555 \mathrm{~g}$ wet $\mathrm{wt} \mathrm{m}^{-2}$. Macrobenthic biomass ( 0.07 to $12.9 \mathrm{~g} \mathrm{~m}^{-2}$; mean $4.18 \pm 0.41 \mathrm{~g} \mathrm{~m}^{-2}$ ) off the northeast shelf appeared to be in conformity with the generalized models presented above.

Species diversity was estimated according to the Shannon-Wiener $H^{\prime}\left(\log _{\mathrm{e}}\right)$ and evenness $\left(J^{\prime}\right)$ indices. In the case of epifauna, the Shannon-Wiener index $H^{\prime}$ (Fig. 7d) ranged between $0.73 \pm 0.09(>100 \mathrm{~m})$ and $2.32 \pm 0.01$ (30 to $50 \mathrm{~m})$. The evenness component $\left(J^{\prime}\right)$ (Fig. $7 \mathrm{C}$ ) varied in conformity with $H^{\prime}$. The low evenness $(0.76 \pm$ 0.16 ) at $>100 \mathrm{~m}$ is in compliance with the presence of specific faunal elements, e.g. Tibia delicatula and Amygdalum watsoni, in the population. In the case of infauna, $H^{\prime}$ (Fig. 8e) generally decreased with depth, evidently as a result of dwindling numbers/species. The evenness component $\left(J^{\prime}\right)$ (Fig. 8d) varied in conformity with $H^{\prime}$. The low evenness $(0.717 \pm 0.07)$ at 101 to $150 \mathrm{~m}$ is attributable to the presence of large numbers of Prionospio sp. and Cossura coasta in the population.

Multiple $k$-dominance plots (Clarke \& Warwick 1994) facilitated discrimination of benthos according to species' relative contribution to standing stocks. While up to 30 species formed $70 \%$ of the total benthos numbers in dredge hauls at 30 to $50 \mathrm{~m}$, it required 8,11 and 1 species to make up this proportion at the depths 51 to 75,76 to 100 and $>100$ m respectively (Fig. 9a). In the case of grab samples (i.e. infauna), 10 species made up to $60 \%$ of the population at 30 to $50 \mathrm{~m}, 6$ each at 51 to 75 and 76 to $100 \mathrm{~m}$, and 1 each at 101 to 150 and $>150$ m (Fig. 9b).

CCA was performed on select (epifaunal and infaunal) species (identified through SIMPER, Tables $5 \& 6$, and BVSTEP), i.e. on the basis of their abundance and in the light of known environmental data. It was found that Axes 1 and 2 on the canonical ordination plots (Fig. 10) were the most important (Table 7) since they were able to explain 74 and $82 \%$ of variation in species abundance data. Monte Carlo permutation tests (with forward selection) were used to identify which environmental variables (out of 10) explained the variance significantly ( $\mathrm{p}<0.05$ level), the benthos distribution, and species abundance patterns (Table 7). For epifauna, the first CCA axis initially separated all shallow sites $(30$ to $50 \mathrm{~m}$ ) from intermediate $(76$ to $100 \mathrm{~m})$ and deeper locations (>100 m), whilst the second CCA axis further separated the intermediate sites (76 to $100 \mathrm{~m}$ ) from deeper sites (>100 m) (Fig. 10). While most of the intermediate sites ( 76 to $100 \mathrm{~m}$ ) are positioned in the upper part of the second axis, the 51 to $75 \mathrm{~m}$ sites are separated and located in the lower part of Axis 2. Axis 1 is strongly associated with depth $(\mathrm{r}=0.80)$ and sediment organic matter $(\mathrm{r}=-0.55)$, whilst sand $(\mathrm{r}=$ $0.46)$ and sediment mean size $(\mathrm{r}=0.48)$ are closely 


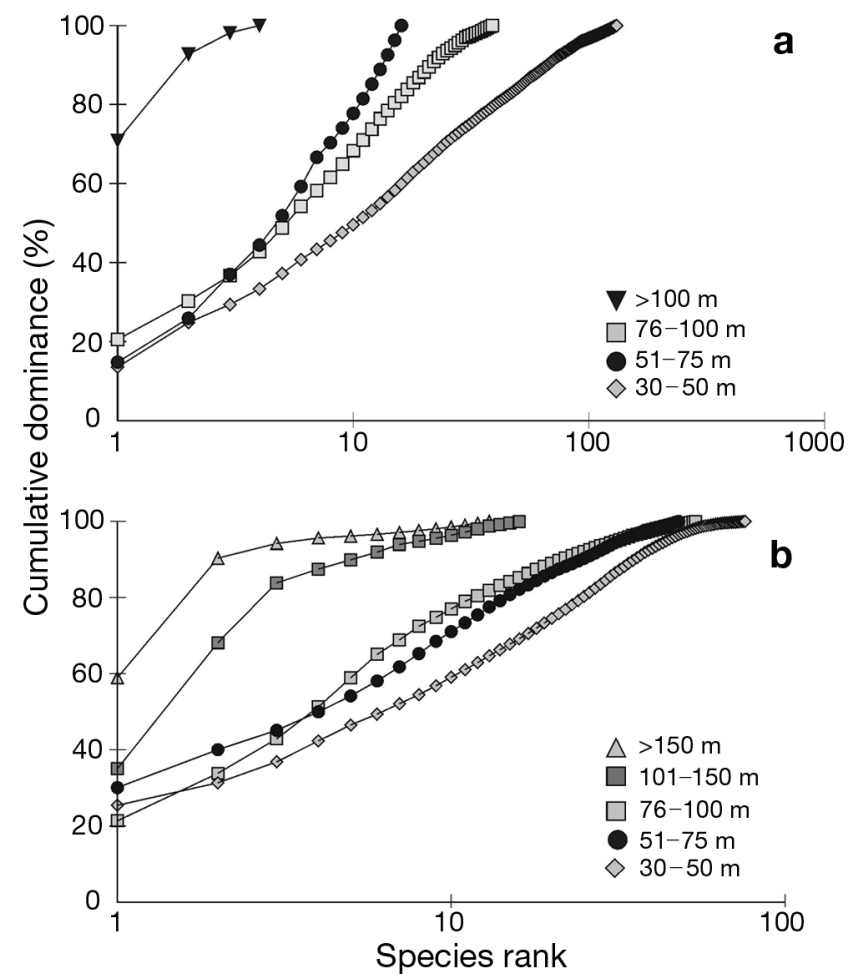

Fig. 9. $k$-dominance curves for species abundance data in relation to depth on the northeast Indian shelf. (a) Dredge haul and (b) grab haul linked with Axis 2. Single variable mean size characterized $(\mathrm{r}=-0.51)$ the third axis (Table 7$)$.

For infauna, the first CCA axis initially separated the shallow sites (30 to $75 \mathrm{~m}$ ) from the intermediate (76 to $100 \mathrm{~m}$ ) and deeper sites (>100 m), whilst the second CCA axis further separated the intermediate sites (76 to $100 \mathrm{~m}$ ) from deeper sites (>100 m). Most of the deeper sites $(>100 \mathrm{~m})$ are positioned in the upper part of the second axis, whereas the intermediate 76 to $100 \mathrm{~m}$ sites are separated and located in the lower part of Axis 2 (Fig. 11). While Axis 1 is strongly influenced by depth $(\mathrm{r}=0.88)$ and sand $(\mathrm{r}=-0.58)$, Axis 4 is linked with temperature $(\mathrm{r}=-0.44)$ and salinity $(\mathrm{r}=0.45)$. Axis 2 did not show any significant correlation, and Axis 3 associated with mean particle diameter $(\mathrm{r}=-0.56)$.

\section{DISCUSSION}

In marine benthic ecology, sediment grain size or granulometry is considered central for determining the composition and characterization of benthos (Sanders 1958, Gray 1974, Rhoads 1974, Snelgrove \& Butman 1994, Wijsman et al. 1999). Gray (1974) observed the lowest diversity within shelf habitats with mud, high diversity in sand habitats and the highest diversity in mixed mud and sand-sediment with a median particle

Table 5. Results of SIMPER analysis for macrobenthic epifauna of the northeast Indian shelf: determining species (bold) for each depth class. Taxa are ranked according to their average contribution to dissimilarity between depths. Group A: 30-50 m; Group B: 51-75 m; Group C: 76-100 m; Group D: >100 m

\begin{tabular}{|c|c|c|c|c|c|c|}
\hline \multirow[t]{2}{*}{ Species } & \multicolumn{2}{|c|}{$\begin{array}{c}\text { Average } \\
\text { abundance }\end{array}$} & \multirow[t]{2}{*}{$\begin{array}{c}\text { Average } \\
\text { dissimilarity }\end{array}$} & \multirow[t]{2}{*}{$\mathrm{SD}$} & \multirow[t]{2}{*}{$\begin{array}{l}\text { Dissimilarity/ } \\
\text { SD }\end{array}$} & \multirow[t]{2}{*}{$\begin{array}{c}\% \\
\text { contribution }\end{array}$} \\
\hline & Group A & Group B & & & & \\
\hline Charybdis sp. & $6.89^{a}$ & 0 & 5.68 & 3.3 & 1.71 & 6.13 \\
\hline Amphioplus depressus & 2.32 & 0 & 3.68 & 3.2 & 1.14 & 3.97 \\
\hline Diopatra neapolitana & 5.74 & 0 & 3.63 & 4.8 & 0.75 & 3.91 \\
\hline \multirow[t]{2}{*}{ Liagore sp. } & 0.16 & $1^{\mathrm{a}}$ & 3.45 & 2.2 & 1.58 & 3.72 \\
\hline & Group C & Group B & & & & \\
\hline \multirow[t]{2}{*}{ Liagore sp. } & 0 & $1^{\mathrm{a}}$ & 5.37 & 2.9 & 1.85 & 5.64 \\
\hline & Group A & Group D & & & & \\
\hline Amygdalum watsoni & 0.05 & $19.5^{\mathrm{a}}$ & 14.72 & 6.8 & 2.18 & 14.81 \\
\hline Tibia delicatula & 0 & $6^{\mathrm{a}}$ & 8.75 & 3.9 & 2.22 & 8.8 \\
\hline \multirow[t]{2}{*}{ Charybdis sp. } & $6.89^{\mathrm{a}}$ & 0 & 5.58 & 3.2 & 1.75 & 5.62 \\
\hline & Group C & Group D & & & & \\
\hline Amygdalum watsoni & 0 & $19.5^{\mathrm{a}}$ & 21.14 & 8.9 & 2.38 & 22.42 \\
\hline \multirow[t]{2}{*}{ Tibia delicatula } & 0.5 & $6^{a}$ & 10.02 & 5.5 & 1.83 & 10.63 \\
\hline & Group B & Group D & & & & \\
\hline Amygdalum watsoni & 0 & $19.5^{\mathrm{a}}$ & 27.98 & 8.6 & 3.26 & 28.4 \\
\hline Tibia delicatula & 0 & $6^{\mathrm{a}}$ & 16.55 & 5.6 & 2.95 & 16.79 \\
\hline Liagore sp. & $1^{a}$ & 0 & 6.89 & 2.7 & 2.56 & 6.99 \\
\hline
\end{tabular}


Table 6. Results of SIMPER analysis for macrobenthic infauna of the northeast Indian shelf: determining species (bold) for each depth class. Taxa are ranked according to their average contribution to dissimilarity between depths. Group A: 30-75 m; Group B: 76-100 m; Group C: >100 m

\begin{tabular}{|c|c|c|c|c|c|c|}
\hline Species & & & $\begin{array}{c}\text { Average } \\
\text { dissimilarity }\end{array}$ & $\mathrm{SD}$ & $\begin{array}{c}\text { Dissimilarity/ } \\
\text { SD }\end{array}$ & $\begin{array}{c}\% \\
\text { contribution }\end{array}$ \\
\hline & Group B & Group A & & & & \\
\hline Ampelisca sp. & 0 & $211.08^{a}$ & 13.33 & 10.5794 & 1.26 & 16.33 \\
\hline Nephtys sp. & $125.38^{a}$ & 45.41 & 7.32 & 7.17647 & 1.02 & 8.97 \\
\hline $\begin{array}{l}\text { Ampelisca sp. } \\
\text { Cossura coasta }\end{array}$ & $\begin{array}{c}\text { Group C } \\
0 \\
174.17\end{array}$ & $\begin{array}{c}\text { Group A } \\
\mathbf{2 1 1 . 0 8}^{\mathbf{a}} \\
10.81\end{array}$ & $\begin{array}{l}16.85 \\
12.81\end{array}$ & $\begin{array}{l}12.8626 \\
13.9239\end{array}$ & $\begin{array}{l}1.31 \\
0.92\end{array}$ & $\begin{array}{l}17.94 \\
13.64\end{array}$ \\
\hline $\begin{array}{l}\text { Cossura coasta } \\
\text { Nephtys sp. }\end{array}$ & $\begin{array}{c}\text { Group C } \\
\mathbf{1 7 4 . 1 7}^{\mathrm{a}} \\
1.67\end{array}$ & $\begin{array}{c}\text { Group B } \\
44.62 \\
\mathbf{1 2 5 . 3 8}^{\mathrm{a}}\end{array}$ & $\begin{array}{l}14.55 \\
13.24\end{array}$ & $\begin{array}{c}13.34 \\
9.52\end{array}$ & $\begin{array}{l}1.09 \\
1.39\end{array}$ & $\begin{array}{l}16.31 \\
14.84\end{array}$ \\
\hline
\end{tabular}

diameter of about $200 \mu \mathrm{m}$, and it is imperative that any correlation between benthic organisms and sediment nature should be viewed as the key to benthic ecology. Seven textural classes (e.g. Sheppard 1954) were observed for the northeast Indian shelf. These included sand, clayey sand, silty sand, sand-silt-clay, silt, silty clay and clayey silt.

Several factors, e.g. locality, depth, distance from the shore, river proximity and local oceanographic features such as bottom currents, etc., appeared important for determining benthos distribution patterns. For example, off Visakhapatnam, sediments within $30 \mathrm{~m}$ typically represented 'sand' and differed markedly from other localities with relatively soft substrata. This is attributable to the absence of any significant river inflows along the Visakhapatnam coast unlike other areas (Divi Point, Kakinada, Barua, Paradip) where heavy sediment loads (rich in silt and clay) enter the sea through the Rivers Krishna, Godavari, Vamsadhara and Mahanadi systems (see Fig. 1). Below 150 m sediments along the northeast shelf are clayey silt, between 50 and $150 \mathrm{~m}$, mostly silt, and from 30 to $50 \mathrm{~m}$, sand, silt and clay, as reported earlier (Subba Rao 1964).

It is generally believed that sediments with coarse particles are deficient in organic matter whereas fine grain sediments show organic enrichment. For the Indian northeast shelf, organic matter correlated sig-
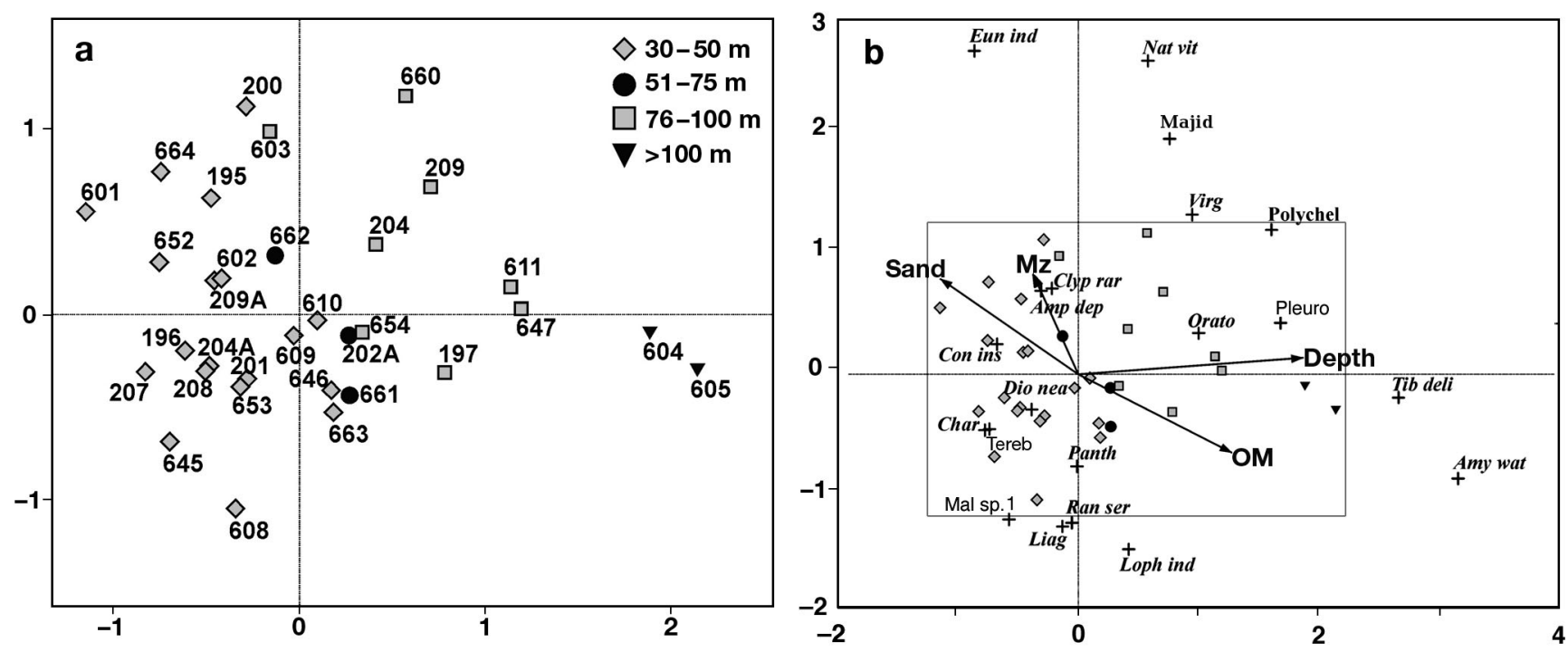

Fig. 10. (a) Canonical correspondence analysis (CCA) showing scatter plot for 32 epifaunal samples on the northeast Indian shelf. (b) CCA showing 20 most important epifaunal species (+), environmental variables, and sampling sites. Vector lines represent the relationship of significant environmental variables to the ordination axes; their length is proportional to their relative significance. OM: organic matter; Mz: sediment mean size. For full species names see Table 3 
Table 7. Results of the CCA: eigenvalues, species-environment correlations and percentage variance for northeast Indian shelf epifauna and infauna abundance data; weighted correlation coefficient between environmental variables and CCA axes. Environmental variables identified by Monte Carlo permutation tests based on forward selection with 499 unrestricted permutations; variance of environmental variables accepted at $\mathrm{p}<0.05$. MPD: mean particle diameter. ${ }^{*}$ Significance at $\mathrm{p}<0.05$ (in bold)

\begin{tabular}{|c|c|c|c|c|c|}
\hline Axes & 1 & 2 & 3 & 4 & Total inertia \\
\hline \multicolumn{6}{|l|}{ Epifauna } \\
\hline Eigenvalues & 0.579 & 0.234 & 0.164 & 0.121 & 4.074 \\
\hline Species-environment correlations & 0.898 & 0.765 & 0.691 & 0.616 & \\
\hline \multicolumn{6}{|l|}{ Cumulative percentage variance } \\
\hline of species data & 14.2 & 20.0 & 24.0 & 27.0 & \\
\hline of species-environment relationship & 52.7 & 74.1 & 89.0 & 100 & \\
\hline \multicolumn{6}{|l|}{ Infauna } \\
\hline Eigenvalues & 0.336 & 0.081 & 0.045 & 0.029 & 1.518 \\
\hline Species-environment correlations & 0.905 & 0.654 & 0.657 & 0.583 & \\
\hline \multicolumn{6}{|l|}{ Cumulative percentage variance } \\
\hline of species data & 22.1 & 27.5 & 30.5 & 32.4 & \\
\hline of species-environment relationship & 66.3 & 82.3 & 91.2 & 97.0 & \\
\hline \multicolumn{6}{|l|}{ Correlation coefficient } \\
\hline \multicolumn{6}{|l|}{ Epifauna } \\
\hline Depth & $0.8064^{*}$ & 0.0786 & 0.1848 & 0.2058 & \\
\hline Sand & $-0.4952^{*}$ & $0^{0.4586}{ }^{*}$ & -0.3603 & 0.1568 & \\
\hline Organic matter & $0.5512^{*}$ & -0.3766 & -0.0513 & 0.3774 & \\
\hline Mean size & -0.1616 & $0.4793^{*}$ & $-0.5162^{*}$ & -0.0798 & \\
\hline \multicolumn{6}{|l|}{ Infauna } \\
\hline Depth & $0.881^{*}$ & -0.087 & 0.095 & 0.064 & \\
\hline Sand & $-0.581^{*}$ & -0.132 & 0.270 & 0.160 & \\
\hline MPD & -0.318 & -0.013 & $-0.562^{*}$ & 0.191 & \\
\hline Temperature & -0.135 & -0.263 & -0.286 & $-0.443^{*}$ & \\
\hline Salinity & 0.092 & -0.135 & -0.303 & $-0.448^{*}$ & \\
\hline
\end{tabular}

nificantly with silt (Pearson correlation $\mathrm{r}=0.52 ; \mathrm{p}<$ $0.05, \mathrm{n}=56)$. Silt increased with depth $(\mathrm{r}=0.427 ; \mathrm{p}<$ $0.05, \mathrm{n}=56)$, as did sediment organic matter $(\mathrm{r}=0.52$, $\mathrm{p}<0.05, \mathrm{n}=56$ ). Off Kakinada, where the River Godavari opens into the sea, sediment organic matter (mean $4.03 \pm 1.42 \%$ ) was highest $(6.084 \%$ ). It is noteworthy that heavy loads of particulate organic carbon $\left(2.81 \times 10^{6} \mathrm{t}\right)$ reach the sea through the River Godavari every year (Prasad 1997).

Benthic faunal abundance decreased in general with depth (Figs. $7 b \& 8 b$ ) as the nature of the sediments (texture and organic content) changed. Nearer shore, while loose sands sheltered rich life (infauna: $1078 \pm$ 593 ind. $\mathrm{m}^{-2}$; epifauna: $82 \pm 55$ ind. haul ${ }^{-1}$ ), the deep muddy (silt) substrata further down remained relatively impoverished $\left(250 \pm 144\right.$ ind. $\mathrm{m}^{-2} ; 15$ ind. haul $\left.{ }^{-1}\right)$. Among the polychaetes, Chloeia rosea and Nereis sp., and ampelisid Ampelisca sp. appeared to prefer sandy substrata, whereas Ancistrosyllis parva, Lumbrineris sp., Prionospio sp., cirratulid, Cossura coasta, Mediomastus sp., and Notomastus sp. favoured finer sediments (silty clay/clayey silt). Off Kakinada, influenced by the massive inflow from the River Godavari, exceptionally high numbers of Prionospio sp. were found, (up to 530 ind. $\mathrm{m}^{-2}$ ). Off the west coast of South Island, New Zealand, including Tasman Bay (Probert et al.
2001), the north Queensland coast, Australia (Alongi \& Christofferson 1992) and the Norwegian Continental Shelf (Ellingsen \& Gray 2002), polychaetes constituted the most dominant group, represented predominantly by spionids. Off Visakhapatnam, spionids contributed heavily $(69.4 \%)$ to the infauna (Raman \& Adiseshasai 1989). In deeper waters (>100 m) with silt or clayey silt sediments, the strombid Tibia delicatula and the mytilid Amygdalum watsoni were, however, the characteristic inhabitants.

Alongi (1990) states that in the Gulf of Mexico crustaceans and echinoderms were the most affected following annual hypoxia events as a result of discharge of large volumes of freshwater and silt into the sea. In the Bay of Ancon off Peru, where oxygen levels become stressful near bottom, the benthos normally suffers from hypoxia, as a result of El Niño and, at times anoxic conditions (Rosenberg et al. 1983). In relatively deep water in the Bay of Bengal $(>75 \mathrm{~m})$, polychaete and crustacean numbers ( 7 to $12 \%$ ), as well as echinoderms (2\%), increased by July 2000 relative to January 1999. There was a marked increase in (mean) dissolved oxygen during the same period, from $0.6 \mathrm{ml} \mathrm{l}^{-1}$ to $\sim 2 \mathrm{ml} \mathrm{l}^{-1}$. As oxygen increased near the bottom, colonization occurred by newly introduced species or by resident species normally held in check 
by the low oxygen conditions. In the Gulf of Panama, recruitment of macrofauna occurred mainly during the latter half of the upwelling (increased levels of oxygen), resulting in high seasonal densities (Alongi 1990).

Diversity appeared largely related to depth, the nature of substratum and/or distance from the shore. While the nearshore (sandy) substrata (depths 30 to $50 \mathrm{~m}$ ) supported a great wealth of life in terms of species richness and abundance, as previously explained, the mid-shelf (51 to $75 \mathrm{~m}$ ) also harboured a good number of species where the sediments contained a mixture of silt and clay. Along several locations on the west coast of India and parts of the southwest Indian Ocean, benthic faunal abundance and diversity have largely been attributed to the sediment nature and depth (Harkantra et al. 1982, Ingole et al. 1992) in conformity with the generalised hypotheses of Sanders (1968). Changes in the macrobenthic faunal community with depth is a widely recognised pattern on continental shelves on the mainland of southern California (Bergen et al. 2001), the west coast of South Island, New Zealand (Probert et al. 2001), and the Bacia de Campos area, southeastern Brazil (Da Silva Attolini \& Santo Tararam 2001).

Off the northeast Indian shelf our findings, which were based on multivariate methods, showed that the benthos could be differentiated into distinct communities separated by depth. Among the epifauna, 3 communities could be distinguished and were named after the most important (determining) species identified by the SIMPER analysis: (1) the Charybdis Assemblage (Group A locations); (2) the Liagore Assemblage (Group B); (3) the Amygdalum watsoni-Tibia delicatula Assemblage (Group D), representing the 30 to 50,51 to 75 , and $>100 \mathrm{~m}$ depth categories respectively. There were, however, no specific species determining the 76 to $100 \mathrm{~m}$ locations. As for the infaunal groups, 3 assemblages named after the most characterizing species could be distin-
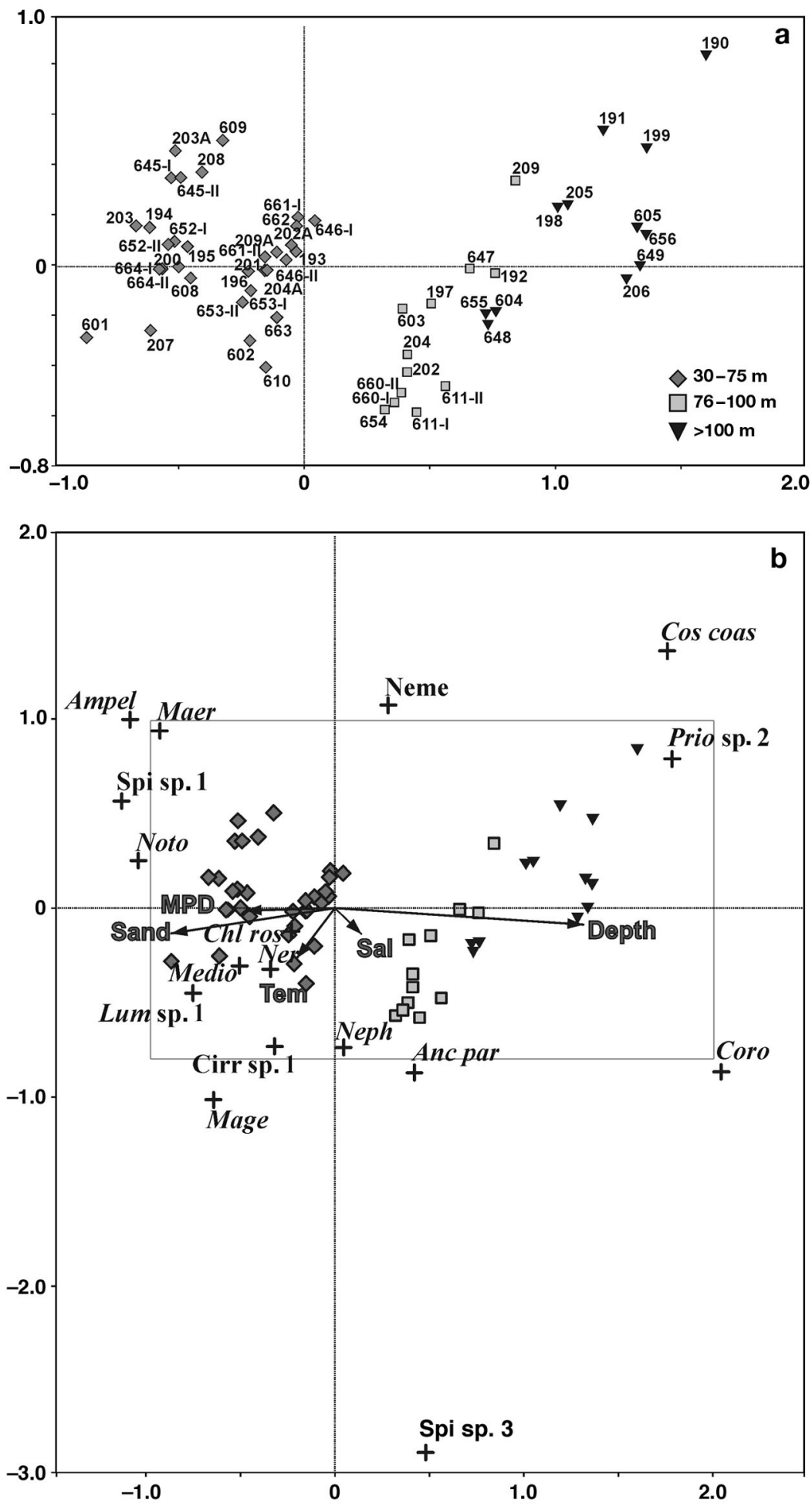

Fig. 11. (a) Canonical correspondence analysis (CCA) showing scatter plot for 62 infaunal samples on the northeast Indian shelf. (b) CCA showing 17 most important infaunal species (+), environmental variables, and sampling sites. Vector lines represent the relationship of significant environmental variables to the ordination axes; their length is proportional to their relative significance. Tem: seawater (bottom) temperature; sal: salinity; MPD: sediment mean particle diameter. For full species names see Table 4 
guished: (1) the Ampelisca Assemblage (Group A locations); (2) the Nephtys Assemblage (Group B); and (3) the Cossura coasta Assemblage (Group C), representing the 30 to 75,76 to 100 , and $>100 \mathrm{~m}$ depth categories respectively.

Using the CCA routine implemented in CANOCO linked benthos communities with environmental variables (sediment texture, particle mean size, MPD, organic matter, dissolved oxygen, salinity and seawater temperature). In the case of epifauna, the first axis of the CCA had an eigenvalue of 0.58 , implying a large percentage of explained variance (ter Braak 1986, Narayanaswamy et al. 2003). The noteworthy feature, however, is the high correlation (weighted correlation coefficient >0.6) between faunal abundance and environmental variables on all 4 CCA axes (Table 7). Considering the epifaunal CCA ordination (Fig. 10), the distribution of some species such as the eunicid Eunice indica, the amphiurid Amphioplus depressus and the cone shell Conus inscriptus was influenced by sand and sediment mean size. In contrast, the strombid Tibia delicatula and the mytilid Amygdalum watsoni seemed to prefer deeper areas with finer sediments rich in organic content. The infaunal $\mathrm{CCA}$, on the other hand, showed that polychaetes Chloeia rosea, Lumbrineris sp., Magelona sp., Mediomastus sp., Nereis sp., and Cirrutulid sp. 1 closely associated with sand with a high MPD. Salinity appeared to relate well with the distribution of the pilargid Ancistrosyllis parva and some spionids and the amphipod Corophium sp. The cossurid Cossura coasta, Prionospio sp. 2 and certain nemertineans negatively correlated with temperature, sand and MPD. In conclusion, our findings have revealed a close concordance between epifaunal patterns and environmental variables, namely depth, sand, sediment organic matter and mean particle size. In the case of infauna, a similar relationship with depth, sand, MPD, (bottom) water temperature and salinity was striking. Monte Carlo permutation tests confirmed the significant association $(p<0.05)$ between environmental variables and the epifauna/infauna distribution off the northeast Indian shelf.

Acknowledgements. This work was carried out with financial assistance provided by the Department of Ocean Development (DOD/10-MLR/10/97-OD-II), Government of India. We are grateful to R. Damodaran, Project Coordinator, School of Marine Sciences, Cochin University of Science and Technology, and V. Ravindranathan, Director at the Centre for Marine Living Resources \& Ecology, Cochin, for encouragement. We are very grateful to Professor J. S. Gray, University of Oslo, who made a critical appraisal of the article and offered invaluable suggestions for its improvement. We express our special appreciation to the Captain and crew of the FORV 'Sagar Sampada' and all those who assisted during the 2 cruises onboard the research vessel. B. T. Sivakumar provided graph- ics. The work, which formed part of PhD research (by T.G.), was carried out at the Marine Biological Laboratory, Department of Zoology, Andhra University. This contribution is dedicated to the late P. N. Ganapati and C.V. Kurian, who initiated marine benthos research in India.

\section{LITERATURE CITED}

Alongi DM (1990) The ecology of soft-bottom benthic ecosystems. Oceanogr Mar Biol Annu Rev 28:381-496

Alongi DM, Christoffersen P (1992) Benthic infauna and organism-sediment relations in a shallow, tropical coastal area: influence of outwelled mangrove detritus and physical disturbance. Mar Ecol Prog Ser 81:229-245

Ansari ZA, Harkantra SN, Nair SA, Parulekar AH (1977) Benthos of the Bay of Bengal: a preliminary account. Mahasagar Bull Natl Inst Oceanogr 10:55-60

Barnes H (1959) Apparatus and methods of oceanography. Part I. Chemical. George Allen \& Unwin, London

Bergen M, Weisberg SB, Smith RW, Cadien DB and 4 others (2001) Relationship between depth, sediment, latitude, and the structure of benthic infaunal assemblages on the mainland shelf of southern California. Mar Biol 138: 637-647

Buchanan JB (1957) Benthic fauna of the continental edge off Accra, Ghana. Nature 179:634-635

Buchanan JB (1958) The bottom fauna across the continental shelf off Accra, Gold coast. Proc Zool Soc Lond 130:1-56

Clarke KR, Gorley RN (2001) PRIMER v5: user manual. PRIMER-E, Plymouth

Clarke KR, Warwick RM (1994) Changes in marine communities: an approach to statistical analysis and interpretation. Plymouth Marine Laboratory, Natural Environmental Research Council, Plymouth

Damodaran R (1973) Studies on benthos of the mud banks of the Kerala coast. Bull Dept Mar Sci Univ Cochin 6:1-126

Da Silva Attolini F, Santo Taram A (2001) Polychaete spatial distribution in the continental shelf of the Bacia de Campos area, Southeastern Brazil. Oceánids 16(1):17-32

Day JH (1967) A monograph on the polychaeta of Southern Africa, Part I (Errantia) \& II (Sedentaria). Trustees of the British Museum (Natural History), London

Dittmann S (2002) Benthic fauna in tropical tidal flats of Hinchinbrook Channel, NE Australia: diversity, abundance and their spatial and temporal variation. Wetlands Ecol Manag 10:323-333

Ellingsen KE, Gray JS (2002) Spatial patterns of benthic diversity: Is there a latitudinal gradient along the Norwegian continental shelf? J Anim Ecol 71:373-389

Fauvel P (1953) The fauna of India including Pakistan, Ceylon, Burma and Malaya. The Indian Press, Allahabad

Ganapati PN (1973) Biological oceanography of the Bay of Bengal. Mahasagar Bull Natl Inst Oceanogr 6(2):84-94

Ganapati PN, Lakshmana Rao MV (1959) Preliminary observations on the bottom fauna of the continental shelf of the north-east coast of India. Proc of the First All-India Congress of Zoology, Part 3. The Zoological Society of India, Kolkata, p 8-13

Gaudette HE, Wilson RF, Lois T, Folger DW (1974) An inexpensive titration method for determination of organic carbon in recent sediments. J Sediment Petrol 44:249-253

Gray JS (1974) Animal-sediment relationships. Oceanogr Mar Biol Annu Rev 12:223-261

Harkantra SN, Nair A, Ansari ZA, Parulekar AH (1980) Benthos of the shelf region along the West coast of India. Indian J Mar Sci 9:106-110 
Harkantra SN, Rodrigues CL, Parulekar AH (1982) Macrobenthos of the shelf off northeastern Bay of Bengal. Indian J Mar Sci 11:115-121

Holme NA, McIntyre AD (eds) (1984) Methods for the study of marine benthos. Blackwell Scientific Publication, Oxford

Ingole BS, Ansari ZA, Parulekar AH (1992) Benthic fauna around Mauritius Island, southwest Indian Ocean. Indian J Mar Sci 21:268-273

Krumbein WC, Pettijohn FJ (1938) Manual of sedimentary petrography. Appleton Century Crofts, New York

Kurian CV (1953) A preliminary survey of the bottom fauna and bottom deposits of the Travancore coast within the 15-fathom line. Proc Natl Inst Sci India 19:746-775

Kurian CV (1971) Distribution of benthos on the southwest coast of India. In: Costlow JD Jr (ed) Fertility of the sea, Vol 1. Gordon and Breach Scientific Publications, New York, p 225-239

LaFond EC (1957) Oceanographic studies in the Bay of Bengal. Proc Indian Acad Sci 46B:1-47

LaFond EC (1966) Bay of Bengal. In: Fairbridge RW (ed) The encyclopedia of oceanography. Encyclopedia of earth science series, Vol. 1. Reinhold Publishing Corporation, New York, p 110-118

Madhupratap M, Mangesh G, Ramaiaha N, Prasanna Kumar S, Muraleedharan PM, de Sousa SN, Sardessai S, Usha Muraleedharan (2003) Biogeochemistry of the Bay of Bengal: physical, chemical and primary productivity characteristics of the central and western Bay of Bengal during summer monsoon 2001. Deep-Sea Res II 50:881-896

Narayanaswamy BE, Nickell, TD, Gage, JD (2003) Appropriate levels of taxonomic discrimination in deep-sea sediments: species vs. family. Mar Ecol Prog Ser 257:59-68

Parulekar AH, Wagh AB (1975) Quantitative studies on benthic macrofauna of the Northeastern Arabian Sea shelf. Indian J Mar Sci 4:174-176

Parulekar AH, Harkantra SN, Ansari, ZA (1982) Benthic production and assessment of demersal fishery resources of the Indian Seas. Indian J Mar Sci 11:107

Prasad GL, Subramanian V, Ittekkot V (1997) Biogeochemistry of particulate organic matter transported by Godavari River, India. Biogeochemistry 38:103-128

Probert PK, Read GB, Grove SL, Rowden AA (2001) Macrobenthic polychaete assemblages of the continental shelf and upper slope off the west coast of the South Island, New Zealand. N Z J Mar Freshw Res 35:971-984

Radhakrishna Y, Ganapati PN (1969) Fauna of the Kakinada Bay. Bull Natl Inst Sci India 38:49-79

Raman AV, Adiseshasai K (1989) Macrobenthos from littoral

Editorial responsibility: John Gray (Contributing Editor), Oslo, Norway areas off Visakhapatnam, east coast of India. Indian $\mathrm{J}$ Mar Sci 18:265-269

Raut D, Ganesh T, Murty NVVS, Raman AV (2005) Macrobenthos of Kakinada Bay in the Godavari delta, east coast of India: comparing decadal changes. Estuar Coast Shelf Sci 62:609-620

Rhoads DC (1974) Organisms-sediment relation on the muddy sea floor. Oceanogr Mar Biol Annu Rev 12:263-300

Rosenberg R, Arntz WE, Chuman de Flores LA, Carbajal G, Finger I, Tarazona J (1983) Benthos biomass and oxygen deficiency in the upwelling system off Peru. J Mar Res 41: 263-279

Sanders HL (1958) Benthic studies in Buzzards Bay. I. Animalsediment relations. Limnol Oceanogr 3:245-258

Sanders HL (1968) Marine benthic diversity: a comparative study. Am Nat 102:243-282

Seshappa G (1953) Observations on the physical and biological features of the sea bottom along the Malabar coast. Proc Natl Inst Sci India 19:257-279

Sheppard FP (1954) Nomenclature based on sand-silt-clay ratios. J Sediment Petrol 24:151-158

Snelgrove PVR, Butman CA (1994) Animal-sediment relationships revisited: cause versus effect. Oceanogr Mar Biol Annu Rev 32:111-117

Subba Rao M (1964) Some aspects of continental shelf sediments off the east coast of India. Mar Geol 1:59-87

Subba Rao NV, Surya Rao KV, Maitra S (1991) Marine molluscs. State Fauna Series 1, Part 3. Fauna of Orissa. Zoological Survey of India, Kolkata, p 1-175

ter Braak CJF (1986) Canonical corespondense analysis: a new eigenvector technique for multivariate direct gradient analysis. Ecology 67:1167-1179

ter Braak CJF, Smilauer P (2002) CANOCO reference manual and user's guide to Canoco for Windows: software for canonical community ordination (version 4.53). Microcomputer power, Ithaca, NY

Varkey MJ, Murty VSN, Suryanarayaya A (1996) Physical oceanography of the Bay of Bengal and Andaman Sea. Oceanogr Mar Biol Annu Rev 34:1-70

Wade BA (1972) A description of a highly diverse soft-bottom community in Kingston Harbour, Jamaica. Mar Biol 13:57-69

Warwick RM, Ruswahyuni (1987) Comparative study of the structure of some tropical and temperate marine softbottom macrobenthic communities. Mar Biol 95:641-649

Wijsman JWM, Herman PMJ, Marian-Traian G (1999) Spatial distribution in sediment characteristics and benthic activity on the northwestern Black Sea shelf. Mar Ecol Prog Ser 181:25-39

Submitted: July 11, 2006; Accepted: December 11, 2006 Proofs received from author(s): June 11, 2007 